\title{
Cystic Lung Disease in Genetic Syndromes with Deficient Tumor Suppressor Gene Function
}

\author{
Cécile Daccord Laurent P. Nicod Romain Lazor \\ Respiratory Medicine Department, Lausanne University Hospital, Lausanne, Switzerland
}

\section{Keywords \\ Lymphangioleiomyomatosis · Angiomyolipoma · Tuberous sclerosis - Sirolimus - Vascular endothelial growth factor D. Birt-Hogg-Dubé syndrome - Tumor suppressor genes . \\ FLCN protein, human $\cdot$ MTOR protein, human}

\begin{abstract}
Cystic lung diseases constitute a distinct group of rare lung disorders, among which two result from monogenic defects affecting tumor suppressor genes: lymphangioleiomyomatosis, either sporadic or associated with tuberous sclerosis complex, and Birt-Hogg-Dubé syndrome. These disorders have similarities in their clinical expression, including occurrence in young adults, multiple pulmonary cysts, recurrent pneumothorax, skin hamartomas, and renal tumors. However, they markedly differ in their gender distribution, pathogenesis, disease course, and prognosis. Our knowledge on these two rare conditions is rapidly expanding. Management of lymphangioleiomyomatosis has substantially improved in the past decade with the understanding of its pathogenic mechanisms, the discovery of an effective therapy, and development of large cohorts and international guidelines. Birt-Hogg-Dubé syndrome has been described more recently and still awaits deeper understanding of its pathophysiology.

(c) 2017 S. Karger AG, Basel
\end{abstract}

\section{Introduction}

The increasing use of chest high-resolution computed tomography (HRCT) has led to better recognition of an imaging pattern characterized by multiple well-delimited hyperlucent zones of the lung parenchyma called pulmonary cysts. Cystic lung diseases now constitute a distinct group of rare lung disorders, with an expanding differential diagnosis. Among these disorders, two are characterized by genetic defects affecting tumor suppressor genes: lymphangioleiomyomatosis (LAM), either sporadic or associated with tuberous sclerosis complex (TSC), and Birt-Hogg-Dubé syndrome (BHD). This review aims at providing the clinician with the main characteristics of these two rare diseases, which share some similar features in their clinical expression, but markedly differ in many other aspects.

Previous articles in this series: 1. Lazor R, Nicod LP: The lung in rare systemic diseases. Respiration 2017;94:1. 2. Tran C, Barbey F, Lazor R, Bonafé L: Pulmonary involvement in adult patients with inborn errors of metabolism. Respiration 2017;94:2-13. 3. Borie R, Wislez M, Antoine M, Cadranel J: Lymphoproliferative disorders of the lung. Respiration 2017;94:157-175. 4. Dupuis-Girod S, Cottin V, Shovlin CL: The lung in hereditary hemorrhagic telangiectasia. Respiration 2017;94:315-330. 5. Uzunhan Y, Jeny F, Kambouchner M, Didier M, Bouvry D, Nunes H, Bernaudin J-F, Valeyre D: The lung in dysregulated states of humoral immunity. Respiration 2017;94:389-404.

\section{KARGER}

(c) 2017 S. Karger AG, Basel

E-Mail karger@karger.com

www.karger.com/res
Dr. Romain Lazor

Service de Pneumologie, Centre hospitalier universitaire vaudois

PMU BU44/07.2137, Rue du Bugnon 44

$\mathrm{CH}-1011$ Lausanne (Switzerland)

E-Mail romain.lazor@chuv.ch 

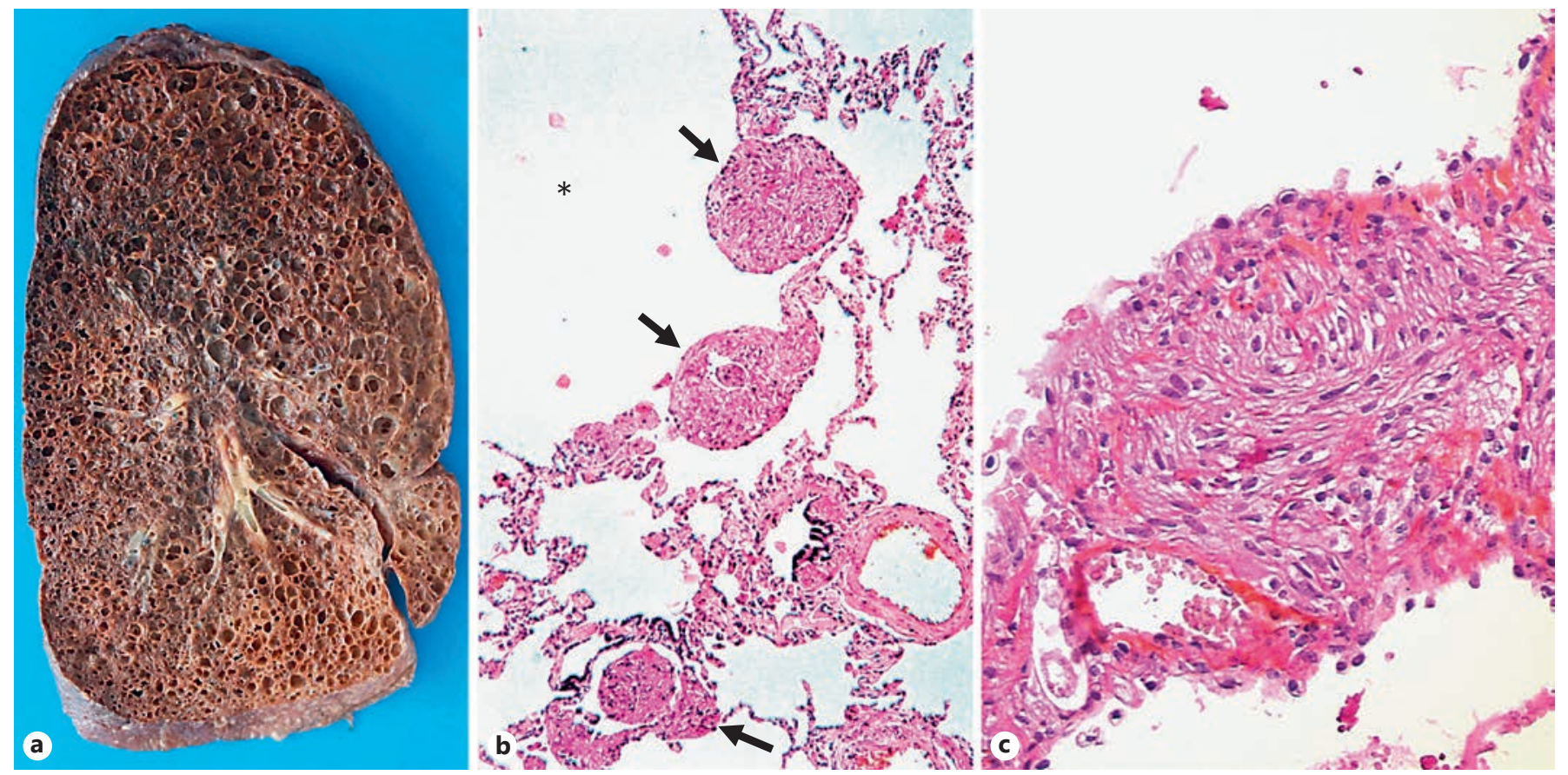

Fig. 1. a Macroscopic view of an explanted lung with lymphangioleiomyomatosis (LAM), showing multiple cysts diffusely distributed through the parenchyma. b Surgical lung biopsy image showing several clusters of LAM cells (arrows) located at the edge of a pulmonary cyst (asterisk). c Close view of a pulmonary LAM cell cluster (courtesy of Dr. I. Letovanec, Institute of Pathology, Lausanne University Hospital, Lausanne, Switzerland).

\section{LAM and Tuberous Sclerosis}

\section{What Is LAM?}

LAM is a rare multisystemic disease occurring almost exclusively in women of childbearing age, either sporadically (S-LAM) or in association with TSC (TSC-LAM). The prevalence of LAM ranges from 2.6 to 7.8 per million women, and the incidence from 0.2 to 0.4 per million women per year [1-3]. In the lungs, LAM is characterized by progressive lung tissue infiltration by atypical smooth muscle-like cells (LAM cells), leading to cystic destruction of the lung parenchyma (Fig. 1a), loss of respiratory function, increasing dyspnea, and recurrent pneumothorax. Extrathoracic manifestations include benign kidney tumors called angiomyolipomas (AML), pleural and peritoneal chylous effusions, thoracoabdominal lymphadenopathy, and chylous abdominal masses called lymphangiomas. Besides these manifestations, which occur in both S-LAM and TSC-LAM, patients with tuberous sclerosis present with additional involvement of various organs.

\section{What Is Tuberous Sclerosis?}

TSC is a genetic autosomal dominant disorder characterized by benign tumors in multiple organs including the skin, brain, retina, kidney, heart, and lung [4-6]. The prevalence of TSC is around $1 / 15,000$. Although TSC is an autosomal dominant disease, most patients have de novo germline mutations and no family history of TSC. The clinical phenotype is highly variable: some patients develop severe neurologic conditions such as seizures or cognitive disability in early childhood, whereas others have only minimal morbidity, which may remain unnoticed until adulthood. Thus, adult patients with TSCLAM may present with only subtle features of TSC which have been overlooked in childhood, or which appeared only in adulthood [7]. These patients are nevertheless at risk of severe manifestations of TSC, and may transmit the disease to their offspring [7].

\section{Clinical Picture and Natural History of LAM}

Most patients with LAM present with lung disease, manifesting mainly as progressive dyspnea and recurrent pneumothorax. A minority of patients present initially 
with symptomatic AML or lymphangiomas, chylous ascites, or chylothorax. LAM may also be discovered incidentally on chest imaging performed for another reason [8].

Lung function in LAM at presentation is mainly characterized by a reduced carbon monoxide transfer factor (DLCO) and an obstructive ventilatory defect, found in up to 80 and $50 \%$ of cases at presentation, respectively [1,9, 10]. Lung function declines at an accelerated rate in LAM as compared to normal subjects. The mean $\mathrm{FEV}_{1}$ loss ranges from 70 to $120 \mathrm{~mL}$ /year $[9,11]$ but is highly variable and cannot be confidently predicted at diagnosis. Ten years after the onset of symptoms, half of patients have mMRC grade 3 dyspnea [12]. In one recent large study, the 10 -year transplant-free survival rate was $86 \%$, and the median transplant-free survival was 29 years from first symptoms and 23 years from diagnosis [13]. Pulmonary hypertension in LAM is rare and of mild severity, and likely results from loss of lung parenchyma and hypoxia rather than vascular disease $[11,14,15]$.

When screened by HRCT, the prevalence of pulmonary LAM in TSC appears to increase with age, from $27 \%$ in women under 21 years to $81 \%$ in women over 40 years [16-19]. At diagnosis of LAM, patients with TSC-LAM have better lung function than patients with S-LAM, although this probably results from earlier diagnosis $[10,20]$. In one study, more than half of the patients with TSC-LAM became symptomatic during the disease course, and 13\% died [17]. The average lung functional decline in TSCLAM is similar to that in S-LAM [21]. Occurrence of LAM in men has exceptionally been reported $[22,23]$, although the presence of a small number of cysts at the lung bases has been described in 13-38\% of men with TSC [24, 25].

Pneumothoraces occur in more than half of LAM patients during the disease course, and frequently recur. Chylothoraces occur in $10-20 \%$ of cases $[1,10]$. AML occur in about $50 \%$ of patients with S-LAM, and in up to $80 \%$ of patients with TSC-LAM, and they are more frequently multiple and bilateral in TSC-LAM [10]. These tumors tend to grow slowly without symptoms but may undergo spontaneous rupture and cause life-threatening bleeding. The risk of bleeding increases up to $50 \%$ when the tumor size reaches more than $4 \mathrm{~cm}$ and/or if vascular aneurysms greater than $5 \mathrm{~mm}$ are present. AML are more likely to bleed in TSC-LAM than in S-LAM [20]. Meningiomas are found in up to $2 \%$ of patients with LAM, i.e., more often than in the general population $[26,27]$.

\section{Histopathology of LAM}

Despite its benign histological appearance, LAM is currently seen as a low-grade neoplasm classified among perivascular epithelioid cell tumors, a group of mesenchymal tumors composed of epithelioid or spindle cells coexpressing smooth muscle and melanocytic markers typically arranged around vessels $[28,29]$. In the lung, LAM cells proliferate around lymphatic vessels, veins, and bronchioles, and form small clusters located in the edge of pulmonary cysts (Fig. 1b, c). LAM lesions contain spindle cells located in the center of the nodular lesions, and epithelioid cells located on the periphery. Both cell types express the smooth muscle markers $\alpha$-actin, vimentin, and desmin. Epithelioid cells also express the melanocytic marker gp 100, which reacts with the human melanin black antibody HMB-45, and spindle cells express the proliferation cell nuclear antigen [30]. LAM cells also express estrogen and progesterone receptors [30], matrix metalloproteinases (MMP) [31], vascular endothelial growth factor receptor 3 [32-35], $\beta$-catenin and E-cadherin [36, 37], CD44v6, an adhesion molecule associated with metastatic behavior [38], and chemokines and chemokine receptors involved in homing of LAM cells to specific organs $[39,40]$. LAM nodules contain cleft-like spaces lined by lymphatic endothelial cells, which express lymphangiogenic factors and their receptors [41].

AML are benign mixed mesenchymal tumors of the kidney consisting of smooth muscle-like spindle-shaped LAM cells, adipocytes, and dystrophic blood vessels. Lymphangiomas are dilated lymphatic vessels forming chyle-filled masses located in the pelvis, retroperitoneum, and posterior mediastinum. They are caused by obstruction to chyle flow due to LAM cell proliferation in the walls of lymphatic vessels.

\section{Imaging of LAM}

On chest HRCT, LAM is characterized by multiple thin-walled, round, well-defined air-filled cysts with preserved or increased lung volumes and no other significant pulmonary involvement. The cysts are usually small with very thin or no visible walls, and evenly distributed throughout all lung fields without any zonal predominance (Fig. 2). Although LAM features appear characteristic on imaging, several other diseases may present with multiple cysts on HRCT (Table 1) [42], including BHD [43-44], pulmonary Langerhans cell histiocytosis (PLCH) [45], and light chain deposition disease [46].

In men and women with TSC, with or without pulmonary LAM, multiple ground-glass nodules predominating in the upper lung zones may be visible. They represent hamartomatous changes called multifocal micronodular pneumocyte hyperplasia (Fig. 3a) [47]. Multifocal mi- 

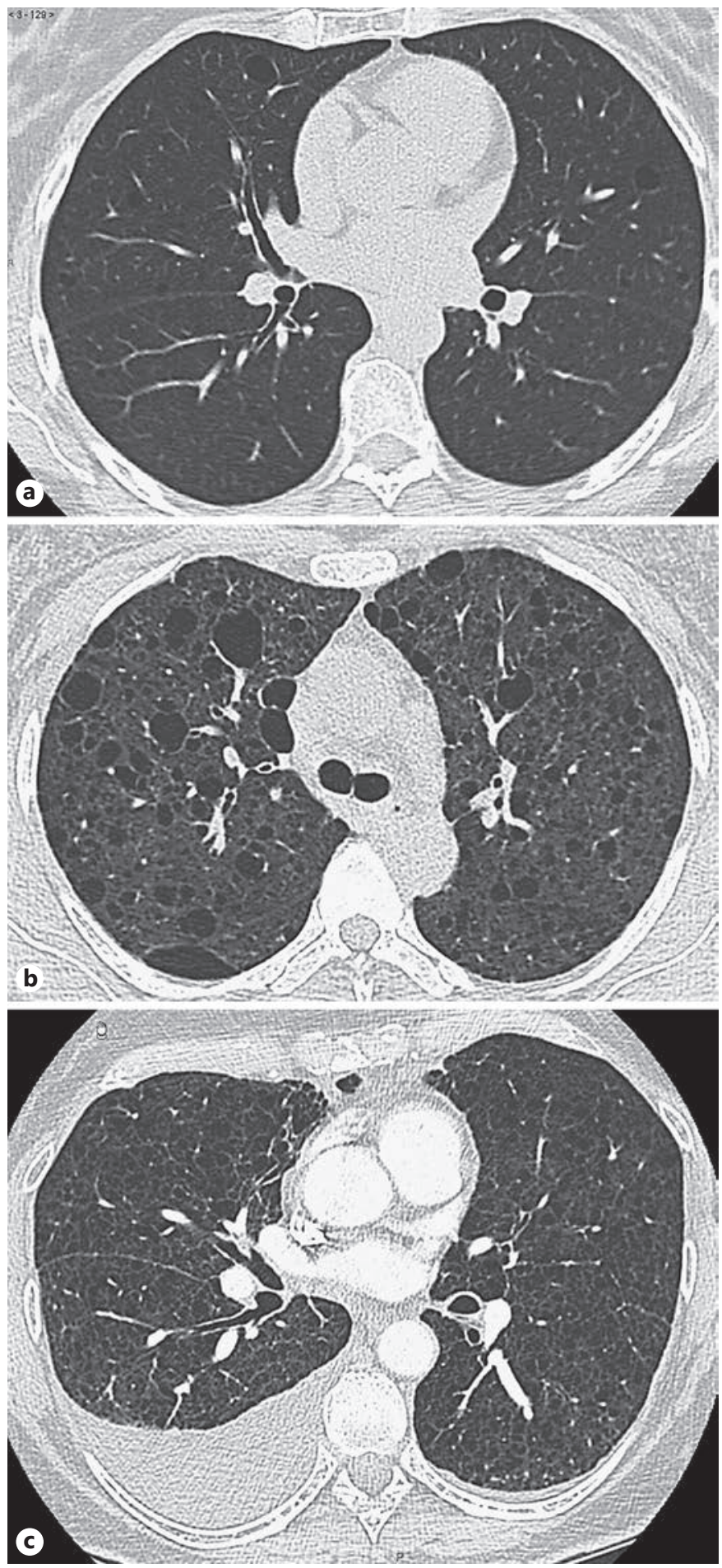

Fig. 2. a High-resolution computed tomography (HRCT) image of early pulmonary lymphangioleiomyomatosis (LAM): a few small, round, well-delimited cysts disseminated in an otherwise normal lung parenchyma. $\mathbf{b}$ HRCT image of more advanced LAM: diffuse parenchymal replacement by numerous cystic spaces. c HRCT image of severe LAM, associated with right chylothorax.
Table 1. Main differential diagnoses of cystic lung diseases

\section{Multiple cysts as the main feature}

Lymphangioleiomyomatosis

Pulmonary Langerhans cell histiocytosis

$\sim 100 \%$

$\sim 100 \%$

Birt-Hogg-Dubé syndrome; familial pneumothorax

Non-amyloid immunoglobulin deposition disease

$\sim 80 \%$

Metastases

$<5 \%$

Other (e.g., Niemann-Pick disease, neurofibromatosis)

\section{Multiple cysts in interstitial lung disease}

Lymphocytic interstitial pneumonia

Hypersensitivity pneumonitis

Sjögren syndrome

Desquamative interstitial pneumonia

Percentages reflect the approximate frequency of multiple lung cysts in each disease, when available.

cronodular pneumocyte hyperplasia is not a feature of S-LAM.

AML present on imaging as heterogeneous lesions containing fat (Fig. 3b). Lymphangiomas appear as wellcircumscribed, loculated masses of variable size with an outer wall and fluid-filled central parts [48, 49] (Fig. 3c). Their size tends to be smaller in the morning after fasting and to increase during the day after meals, which increase lymph flow from the digestive tract $[50,51]$.

\section{Pathogenesis of LAM}

Genetic Events

The genes responsible for TSC have been characterized in the 1990s [52, 53], and subsequent work has demonstrated the role of TSC mutations in the pathogenesis of S-LAM $[34,35]$. LAM cells in patients with S-LAM and TSC-LAM bear mutations in the tuberous sclerosis genes TSC1 and more frequently TSC2, respectively coding for the proteins hamartin and tuberin. Hamartin and tuberin form an intracellular dimer which inhibits the mechanistic target of rapamycin (mTOR), a kinase playing a central role in the regulation of cell growth and proliferation.

S-LAM is caused by mutations in the TSC2 gene [34, 35]. TSC is caused by mutations in the TSC1 or TSC 2 gene, the latter usually resulting in a more severe clinical phenotype [54]. TSC mutations presumably occur through two consecutive genetic hits [55]. In patients with TSC-LAM, a germline mutation of a TSC gene is present in one allele, and a second sporadic mutation occurs after conception in the second allele of the same gene, resulting in loss of heterozygosity of the normal allele, and loss of the corresponding protein product hamartin or tuberin. In patients with S-LAM, no germline 

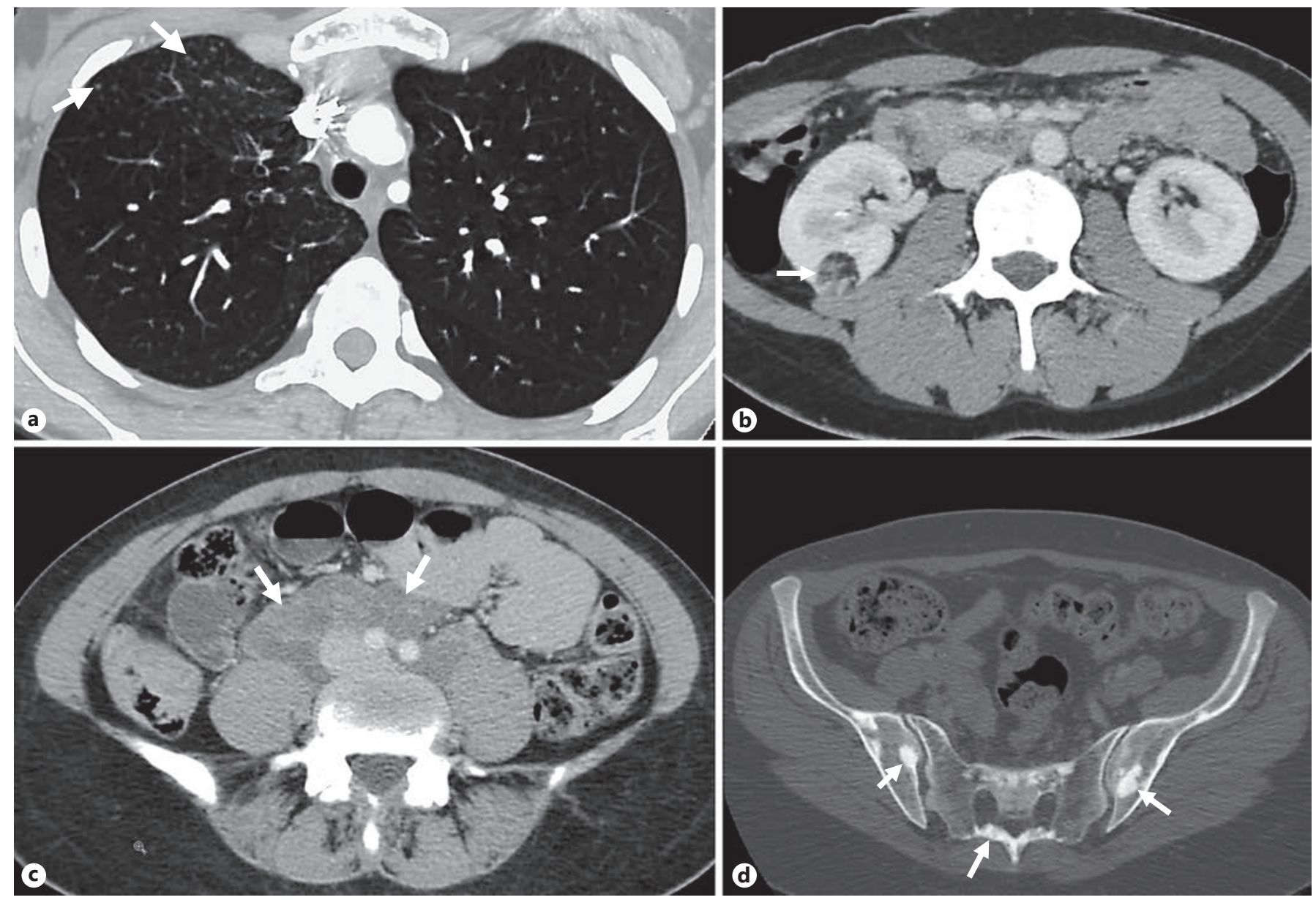

Fig. 3. a Multifocal micronodular pneumocyte hyperplasia in tuberous sclerosis. Multiple, rounded, ground-glass opacities predominating in the right upper lobe (arrows). b Single angiomyolipoma of the right kidney: heterogeneous mass with a fatty component of low density (arrow). c Abdominal lymphangioma in tuberous sclerosis, presenting as loculated mass with a thin outer wall and low-density fluid-filled central part (arrows). d Dense sclerotic lesions of the pelvic bone in tuberous sclerosis (arrows).

mutation has been detected so far, and both genetic hits are thought to occur consecutively in somatic cells after conception $[34,35]$.

\section{Cellular Events}

The role of tuberin as a regulator of cell growth was first identified in the fly Drosophila melanogaster [56]. In the physiologic state, the hamartin-tuberin complex constitutes a critical regulatory point which integrates signals on cell nutritional and energetic status, amino acids, growth factors, and stress, and modulates the activity of mTOR through the GTPase Ras homolog enriched in brain. mTOR is constituted of two distinct complexes: mTORC1, which controls glucose uptake, lipid metabolism, protein translation, and nucleotide synthesis and is sensitive to inhibition by rapamycin (sirolimus), and mTORC2, which regulates cell proliferation, assembly of the actin cytoskeleton, and cell survival, and is activated by insulin and insensitive to sirolimus. The loss of upstream negative regulation of mTOR due to a defective hamartin-tuberin complex induced by TSC gene mutations leads to constitutive overactivation of mTOR. Activation of mTOR leads to metabolic reprogramming, resulting in increased glucose uptake, de novo synthesis of proteins, lipids, and nucleotides, and uncontrolled cell growth, proliferation, motility, and survival $[57,58]$. Interestingly, the amino acid-induced activation of mTOR is also regulated by the 
tumor suppressor protein folliculin (FLCN), mutations of which cause BHD $[59,60]$.

Observations that LAM occurs almost exclusively in women of childbearing age, may worsen during pregnancy and estrogen therapy $[59,61]$, and stabilize after menopause $[61,62]$, as well as the presence of hormonal receptors on LAM cells, suggest that LAM is a hormone-sensitive disorder. Indeed, it has been shown that estrogens promote the growth of human AML cells [63], the invasiveness of human LAM cells in vitro [64], and pulmonary metastases of tuberin-null cells in a mice model of LAM [65].

\section{Dissemination of LAM Cells}

The source organ and the normal histological counterpart of LAM cells are currently unknown. One study suggested that LAM cells originate from uterine leiomyomas, as clusters of LAM cells were found in $90 \%$ of hysterectomy specimens from LAM patients but not in control subjects [66]. However, only $40 \%$ of patients with LAM have uterine leiomyomas [1]. Other putative sources of LAM cells are renal AML, axial lymphatics [67], and perivascular epithelioid cell tumors [66].

Several observations have led researchers to consider that the involvement of multiple organs in LAM is the result of metastatic spread of LAM cells. In rare cases of LAM recurrence after lung transplantation, LAM cells identified in the lung allograft were found to originate from the recipient $[68,69]$. In over $90 \%$ of LAM patients, LAM cells can be identified in bronchoalveolar lavage fluid, blood, chylous effusions, or urine, usually consisting of one cell clone, although multiple clones have been found in up to $25 \%$ of cases [70-72]. These findings support the hypothesis of a metastatic mechanism of LAM cell dissemination. LAM cells are thought to circulate through lymphatics in clusters covered by a layer of endothelial cells, to enter the venous system, and to follow the bloodstream to reach the lung microvasculature [57].

\section{Pulmonary Events}

The mechanisms leading to cystic destruction of the lung parenchyma are incompletely understood. Development of cystic spaces is associated with proliferation of type II pneumocytes and destruction of elastic and collagen fibers in the walls of lung cysts. The latter has been attributed to the proteolytic action of MMP, which are overexpressed in LAM nodules [64, 73]. Cathepsin K, a collagenase and elastase regulated by $\mathrm{mTOR}$, is also strongly expressed in LAM cells, and may contribute to the proteolytic environment leading to cystic lung de- struction. Since LAM nodules contain lymphatic vessels and express lymphangiogenic factors and their receptors, it has also been suggested that lung cysts may represent a form of disorganized lymphangiogenesis [57].

\section{Diagnosis of LAM}

Imaging

Suspicion of LAM usually starts with the finding of multiple cysts on HRCT in a woman. However, even if the finding is typical, HRCT alone is insufficient to establish a firm diagnosis of LAM, and additional features are required. ERS guidelines have proposed a set of imaging and clinical criteria for diagnosing LAM [74] (Table 2).

Abdominopelvic CT may identify features of LAM or TSC, including AML, lymphadenopathy, lymphangiomas, or chylous ascites. AML can usually be diagnosed by imaging only if the fatty component is well visible as a low-attenuation opacity associated with a heterogeneous mass (Fig. 3b). A study on thoracoabdominal CT in patients with S-LAM and TSC-LAM using bone window settings has shown that patients with TSC-LAM, in contrast to those with S-LAM, frequently present with multiple sclerotic bone lesions [75] (Fig. 3d). The presence of more than 4 of such lesions has been suggested to differentiate TSC-LAM from S-LAM with $89 \%$ sensitivity and $97 \%$ specificity [75].

\section{Clinical Search for TSC Features}

TSC should be carefully looked for in all patients with newly diagnosed LAM. The diagnosis of TSC is based on international criteria [5], and requires at least a detailed examination of the skin, eyes, and nervous system, as well as brain imaging.

\section{Vascular Endothelial Growth Factor D}

VEGF-D is a major angiogenic growth factor produced especially by malignant cells which promotes the formation of lymphatics and spread of tumor cells to lymph nodes. LAM cells express the lymphangiogenic factors VEGF-C and VEGF-D and their receptors VEGFR-2 and VEGFR-3 [67]. In TSC2-deficient cells in vitro, VEGF secretion is markedly elevated and this effect is only partly reverted by sirolimus, suggesting that tuberin regulates VEGF through both mTOR-dependent and mTOR-independent pathways [76]. Serum VEGF-D is increased in $70 \%$ of patients with LAM $[32,33]$, but not in patients with other cystic lung diseases, such as PLCH, emphysema, Sjögren syndrome, and BHD, as well as in healthy controls [77, 78]. A VEGF-D level above $800 \mathrm{pg} /$ $\mathrm{mL}$ identified LAM among patients with various cystic 
lung diseases with $73 \%$ sensitivity and $100 \%$ specificity [78]. In one retrospective study, the use of VEGF-D allowed reducing by $10 \%$ the need for surgical lung biopsy (SLB) to achieve a definite diagnosis of LAM [79]. Based on these data, ATS/JRS guidelines recommend using VEGF-D testing for the noninvasive diagnosis of LAM in patients with characteristic HRCT but no other extrathoracic features [19].

\section{Biopsy}

SLB with immunostaining for smooth muscle actin and HMB-45 had long been the standard method for LAM diagnosis, until its characteristic appearance on HRCT was recognized. Currently, the diagnosis of LAM can in most cases be confidently made according to clinical and imaging criteria [74] and VEGF-D testing [19], and SLB is less frequently needed. Recent data suggest that transbronchial biopsy can be safely performed in LAM with a diagnostic yield of $40-60 \%$ [80-82], and may thus constitute a less invasive alternative to SLB. The use of cryobiopsy has been reported in one case [83]. Tissue is sometimes obtained from other locations, such as abdominopelvic lesions.

\section{Diagnostic Strategy}

A stepwise approach is recommended to establish a confident diagnosis in the least invasive manner. A clinical search for TSC and thoracoabdominal imaging should be the initial steps, followed by VEGF-D testing. Transbronchial biopsy or SLB should be restricted to patients with LAM features on HRCT but with no extrathoracic findings supporting the diagnosis and serum VEGF-D below $800 \mathrm{pg} / \mathrm{mL}$. In patients with typical HRCT findings, no symptoms, and near-normal lung function, a definite diagnosis may not be required immediately, and regular follow-up of lung function may initially be sufficient. However, if sirolimus treatment is considered, a definite diagnosis should be obtained.

\section{Management}

Initial Assessment and Follow-Up

Complete lung function testing should be performed at diagnosis. Follow-up is recommended every 3-6 months during the first year or if disease progression is observed, and every 6-12 months if the disease appears stable [74]. The follow-up of patients with TSC-LAM should be the same as for S-LAM.

Besides its diagnostic value, VEGF-D may provide additional prognostic information on disease severity, as higher serum VEGF-D levels were correlated with lower
Table 2. Diagnostic criteria for LAM according to the ERS international guidelines [74]

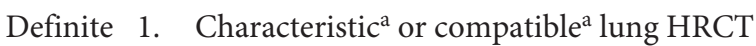

LAM and lung biopsy fitting the pathological criteria for LAM

OR

2. Characteristic ${ }^{\mathrm{a}}$ lung HRCT and any of the following:

- angiomyolipoma (kidney) ${ }^{\mathrm{b}}$

- thoracic or abdominal chylous effusion ${ }^{c}$

- lymphangioma ${ }^{\mathrm{d}}$ or lymph node involved by LAM $^{\mathrm{d}}$

- definite or probable TSC

Probable 1. Characteristic ${ }^{\mathrm{a}}$ HRCT and compatible clinical

LAM history

OR

2. Compatible ${ }^{a}$ HRCT and any of the following:

- angiomyolipoma (kidney) ${ }^{\mathrm{b}}$

- thoracic or abdominal chylous effusion ${ }^{\mathrm{c}}$

\section{Possible $\quad$ Characteristic $^{\mathrm{a}}$ or compatible ${ }^{\mathrm{a}} \mathrm{HRCT}$}

LAM

Comments: (1) LAM is considered to be associated with TSC when definite or probable TSC is present. Otherwise LAM is considered sporadic. (2) The diagnosis of LAM defined above is only for women. LAM is most exceptional in men without TSC and exceptional in men with TSC. In these, a diagnosis requires characteristic or compatible HRCT and typical pathological features. (3) The diagnosis of LAM requires the exclusion of other causes of cystic lung disease. A complete diagnostic workup for these alternative causes is necessary in patients with probable/possible LAM. LAM, lymphangioleiomyomatosis; HRCT, high-resolution computed tomography; TSC, tuberous sclerosis complex. ${ }^{\text {a }}$ Characteristic HRCT: multiple thin-walled, round, well-defined air-filled cysts with a preserved or increased lung volume with no other significant pulmonary involvement (except multifocal micronodular pneumocyte hyperplasia in patients with TSC); compatible HRCT: the same as above, but with only few (2-10) cysts. ${ }^{\mathrm{b}}$ Diagnosed by $\mathrm{CT}$ features and/or histopathology. ${ }^{\mathrm{c}}$ Based on visual and/or biochemical characteristics. ${ }^{\mathrm{d}}$ Based on histopathology. ${ }^{\mathrm{e}}$ See Northrup and Krueger [5]. ${ }^{\mathrm{f}}$ Pneumothorax (multiple/bilateral) and/or altered lung function as in LAM.

$\mathrm{FEV}_{1} / \mathrm{FVC}$ and DLCO/VA ratios [32], more severe disease at imaging [16], and faster lung functional decline [18, 84]. VEGF-D also appears more elevated in patients with lymphatic disease and chylous effusions than in those with only cystic lung disease or AML $[16,85]$.

\section{General Measures and Patient Information}

Nonspecific therapeutic measures include inhaled bronchodilators if airflow obstruction is present, smoking cessation, influenza and pneumococcal vaccination, 
and pulmonary rehabilitation $[74,86]$. About $25 \%$ of patients have a significant response to bronchodilators [11, 87]. Osteopenia is common in LAM [88], and periodic evaluation of bone mineral density and treatment of osteoporosis are recommended [74].

LAM patients should be informed of the high risk of pneumothorax, and advised to consult a physician if they develop sudden shortness of breath and/or chest pain [74]. A 2\% incidence of flight-associated pneumothorax has been reported in LAM $[89,90]$. Recommendations on this issue can be found elsewhere [74]. Avoidance of estrogens is recommended, including combined contraceptive pills and hormone replacement therapy. The preferred contraceptive methods include progesteronebased oral contraceptives or drug-eluting intrauterine devices. Retrospective series suggest that pregnancy may increase the incidence of pneumothorax and chylothorax, accelerate lung functional decline, and increase the risk of AML bleeding [1, 2, 91]. LAM patients with mild disease who want to become pregnant should be informed of the increased risk of complications [74], and it may be appropriate to discourage those with severe disease from becoming pregnant. Patients with TSC should receive genetic counselling prior to conception.

Patients with AML should be instructed to recognize symptoms of bleeding such as abdominal or flank pain, hematuria, a palpable abdominal mass, or shock, and be advised to request urgent medical attention if such symptoms occur [74]. Patients should be informed about patient associations and support groups.

\section{Management of Pneumothorax}

Pneumothorax occurs in two-thirds of patients during the disease course and is highly recurrent. The relapse rate is reduced from $66 \%$ after conservative treatment to $27-32 \%$ after pleurodesis $(p<0.01)$ [92]. Pleurodesis should be performed after the first pneumothorax, preferably by pleural abrasion. A new technique of total pleural covering could further reduce the relapse rate [93].

\section{Management of Parenchymal Lung Disease}

The discovery of the role of mTOR activation in LAM pathogenesis - and the availability of sirolimus (rapamycin), an mTOR inhibitor used for renal transplantation - has allowed rapid therapeutic advances. The beneficial effect of sirolimus on lung function in LAM has been demonstrated in observational studies $[85,94-96]$ and a randomized controlled trial [97]. In the latter study, 89 patients were randomized to receive sirolimus or placebo during 12 months, followed by an observation period of
12 months without treatment. While a decline in $\mathrm{FEV}_{1}$ was observed under placebo, sirolimus provided stabilization of $\mathrm{FEV}_{1}$, with a statistically significant difference of $153 \mathrm{~mL}$ between groups [97]. During the 12-month follow-up after sirolimus discontinuation, $\mathrm{FEV}_{1}$ declined at the same rate in both groups. The main adverse events were mouth ulcers, diarrhea, nausea, increased blood cholesterol levels, skin rash, and swelling of the extremities [97]. This study showed that sirolimus stabilizes lung function in LAM, but that continuous therapy is needed. Long-term observational studies showed that the efficacy of sirolimus is maintained over several years [85, 95, 98, 99]. One small series suggested that a low dose of sirolimus $(1 \mathrm{mg} /$ day) resulting in serum levels below $5 \mathrm{ng} / \mathrm{mL}$ may be sufficient to stabilize lung function [100]. Everolimus, an analog of sirolimus, also stabilized lung function in one observational study [101]. International guidelines now recommend that sirolimus be introduced in LAM patients if their lung function is abnormal $\left(\mathrm{FEV}_{1}\right.$ $<70 \%$ predicted) or declining (an $\mathrm{FEV}_{1}$ loss $>90 \mathrm{~mL} /$ year over 6-18 months has been proposed as a threshold) [19].

Hormonal treatments (including oophorectomy, progesterone, antiestrogen, and gonadotropin-releasing hormone) have been largely used in LAM patients, but inconsistent results have been reported $[62,102]$, and no randomized trial is available. These therapies are no longer recommended [19]. Doxycycline, an inhibitor of MMP, was studied after a case report had suggested its efficacy in improving lung function [103], but no benefit was observed in one small randomized trial [104], and this treatment is not recommended [19]. Therapeutic strategies under investigation include autophagy inhibition by hydroxychloroquine [105] and reduction of estrogen synthesis by letrozole [106].

Lung transplantation is an effective therapy in advanced LAM [107-111]. The posttransplant survival with LAM is similar or even better than with other indications. Recurrence of LAM in the transplanted lung has been reported in $4-7 \%$ of cases, but this is usually an incidental finding which does not affect survival [107, 109-111]. Seventy to $90 \%$ of LAM transplant candidates have a history of previous pleurodesis, and this intervention is associated with an increased technical difficulty of transplantation and a higher risk of perioperative bleeding [107, 109-111]. However, previous pleurodesis does not constitute a contraindication to transplantation. As comorbidities occur in TSC, patients with TSC-LAM should have a careful multidisciplinary pretransplant evaluation, but TSC is not a contraindication to transplantation. Sirolimus is contraindicated immediately after transplan- 
tation as it may induce dehiscence of bronchial sutures $[112,113]$, but it has been used at a later stage to manage LAM-specific complications [114-117]. Whether sirolimus should be stopped when patients are listed for transplantation to avoid being on therapy during the perioperative period is currently unclear.

\section{Management of Chylous Effusions}

Chylothorax of variable severity occurs in $10-20 \%$ of LAM patients, including postoperatively after transplantation. Observation or thoracocentesis may be sufficient for small effusions, but large and recurrent effusions require therapy. Various strategies have been attempted, including pleurodesis, thoracic duct ligation or vaso-occlusion, pleuroperitoneal shunt, and fat-free diet. However, demonstration of the efficacy of sirolimus for chylous effusions has strongly modified the therapeutic approach $[95,100]$, and sirolimus is now considered the first-line therapy for chylous manifestations in LAM [19]. A response may, however, take several months to develop.

\section{Management of AML}

Screening for AML is recommended at diagnosis of LAM, and AML should be followed by imaging (preferably magnetic resonance imaging [MRI]) on a yearly basis. AML larger than $4 \mathrm{~cm}$ or with vascular aneurysms greater than $5 \mathrm{~mm}$ should be preventively treated to avoid hemorrhagic complications. Treatment of AML with mTOR inhibitors has been examined in open-label studies $[94,118,119]$ and a randomized controlled trial [120]. Sirolimus or everolimus decreased the mean AML size by $26 \%$ to $53 \%$, and about $40 \%$ of patients had a volume reduction greater than $50 \%$. In a follow-up study, the benefit was maintained after 4 years, and no AML bleeding was observed [119]. Pharmacological treatment is thus recommended for asymptomatic AML larger than $3 \mathrm{~cm}$ [6], especially when multiple. Embolization is an alternative, especially for solitary AML. For an acutely bleeding AML, embolization is the first-line therapy [6]. Nephronsparing surgery is an acceptable alternative.

\section{Birt-Hogg-Dubé Syndrome}

\section{What Is BHD?}

$\mathrm{BHD}$ is a rare inherited autosomal dominant disorder caused by germline mutations in the tumor suppressor gene FLCN encoding the protein folliculin. Its typical manifestations include cutaneous fibrofolliculomas, mul- tiple pulmonary cysts, recurrent spontaneous pneumothorax, and renal tumors of various histological types.

The syndrome is named after the physicians who described the cutaneous phenotype of the disease and its autosomal dominant inheritance in 1977 [121]. The association with renal tumors, pulmonary cysts, and spontaneous pneumothorax, suggested in prior case reports [122-125], was more extensively described in 1999 [126]. The gene locus responsible for BHD was located on the short arm of chromosome 17 in 2001 [127, 128], and the FLCN gene was eventually identified in 2002 [129]. By February 2016, 183 different FLCN mutations had been identified in $616 \mathrm{BHD}$ families (BHD Foundation; https:// www.BHDsyndrome.org). It has recently been suggested that BHD be renamed as "FLCN (folliculin) gene-associated syndrome" or "FLCN syndrome" based on the present state of knowledge on the disease [130].

\section{Pathogenesis}

The majority of mutations identified in the FLCN gene result in loss of function of the protein folliculin [131]. It was therefore suggested that FLCN acts as a tumor suppressor gene $[132,133]$. Folliculin is expressed in most tissues, including the lung, skin, and kidneys $[134,135]$. Its exact function is unknown, but it is thought to be involved in the regulation of cell growth, proliferation, and survival through interactions with the mTOR signaling pathway $[59,136]$.

The mechanism by which loss of folliculin function results in the formation of pulmonary cysts remains unclear. Dysregulation of different signaling pathways has been described, including mTOR and 5' AMP-activated protein kinase $[137,138]$, as well as impaired cell-cell adhesion [139] and imbalance of extracellular matrix homeostasis through alterations in MMP [140]. It was recently hypothesized that pulmonary cysts could result from defects in cell-cell adhesion, leading to repeated stretch-induced stress caused by breathing and, in the long term, to expansion of alveolar spaces, primarily in regions subject to larger changes in alveolar volume during the breathing cycle. This theory could explain the predominantly basal and subpleural distribution of lung cysts in BHD [141].

\section{Clinical Picture}

The condition displays great phenotypic heterogeneity. Individuals with FLCN mutations may be asymptomatic or present with any combination of skin, pulmonary, or renal manifestations. The typical clinical picture shows cutaneous lesions and spontaneous recurrent pneumo- 
thorax due to pulmonary cysts. However, some patients present with pulmonary cysts and/or relapsing pneumothorax without any skin or renal involvement [142-147]. The disease has no gender predilection [148], and it typically manifests in the $3 \mathrm{rd}$ or 4 th decade of life but can affect individuals at any age [149]. Asian patients seem to have a lower incidence of cutaneous and renal manifestations but a higher recurrence rate of pneumothorax than Caucasians [146, 147, 150-152].

\section{Pulmonary Manifestations}

Multiple bilateral pulmonary cysts are found in more than $80 \%$ of patients with BHD $[43,132,153]$. The cysts tend to develop in the 4 th to 5 th decade of life $[144,147]$ but can be seen in younger adults [154]. The cysts are prone to rupture and predispose to spontaneous pneumothorax at a high recurrence rate. The risk of pneumothorax is estimated to be 50 -fold higher than in the general population [153]. However, the prevalence rates of spontaneous pneumothorax vary considerably depending on the cohorts analyzed [155], ranging from 23-38\% in renal/dermatologic cohorts $[43,132,153,156,157]$ to $42-76 \%$ in pulmonary cohorts $[151,158,159]$. In three large cohorts, the mean age at occurrence of the first pneumothorax was between 36 and 38 years [43, 156, 159]. The rate of recurrence is $75-82 \%$, with an average number of 3.6 episodes [43, 159]. When pleurodesis is performed, the recurrence rate is halved from more than $60 \%$ with conservative management to approximately $30 \%$ [159].

Risk factors for the occurrence of pneumothorax in BHD include the presence of pulmonary cysts; the number, size, and total volume of the cysts; and a family history of pneumothorax $[43,157]$. There is no gender predilection for pulmonary cysts and/or pneumothorax, nor any association with smoking or the presence and/or severity of cutaneous and renal involvement $[43,153]$. The risk of pneumothorax is thought to be increased during and following air travel or diving due to atmospheric pressure changes causing cyst expansion and favoring their rupture. The flight-related pneumothorax rate with BHD was estimated to range from 0.12 to $0.63 \%$ per flight [158-160]. While the vast majority of BHD patients experiencing pneumothorax have pulmonary cysts [157], there have been reported cases of pneumothorax without obvious cysts on HRCT [161, 162].

Apart from episodes of pneumothorax, the cystic lung disease in BHD is usually asymptomatic, or only causes mild exertional dyspnea and/or cough, even when lung involvement is extensive. The data on lung function in
BHD are limited to case reports or small series $[154,163$, 164]. In 14 patients with baseline data only, the pulmonary function test results were essentially normal with mean spirometric values within the normal range and minimally reduced DLCO [165]. Whether pulmonary function declines over time is currently unknown. It seems, however, that the lung involvement in BHD does not usually result in respiratory failure.

Although some studies have reported the occurrence of lung adenocarcinoma, atypical adenomatous hyperplasia, or micronodular pneumocyte hyperplasia-like lesions in patients with BHD [144, 151, 163, 166], no association with pulmonary neoplasms has been formally established so far.

\section{Cutaneous Manifestations}

Skin involvement is common in BHD, and may be the first symptom of the disease [43, 132, 156, 161, 167]). Typical manifestations include fibrofolliculomas, trichodiscomas, and acrochordons. [135, 149]. They usually appear in the 3rd to 4 th decade, and are only exceptionally seen before the age of 25 years $[132,161]$. The most frequent and characteristic lesions are fibrofolliculomas, which are macroscopically undistinguishable from trichodiscomas [161]. They both represent benign hamartomas of the hair follicles and likely belong to the same morphological spectrum $[164,168-170]$. They present as multiple characteristic, whitish, dome-shaped, smooth papules with a diameter of $2-4 \mathrm{~mm}$ occurring primarily on the nose and cheeks, in the retroauricular area, and on the neck and upper chest (Fig. 4a) [171]. Acrochordons, also known as skin tags, are small, soft, skin-colored benign tumors with thin necks mainly distributed on the eyelids, neck, and axilla. They are often seen in BHD, but are also very common in the general population [172]. The identification of fibrofolliculomas should raise suspicion of BHD and lead to further investigations to confirm the diagnosis and screen for renal tumors and pulmonary cysts.

\section{Renal Manifestations}

Renal cancer represents the most threatening manifestation of BHD. The prevalence of renal tumors is approximately $30 \%$ [132, 151, 153, 157, 173], with a 7-fold increased risk of developing renal cancer compared to unaffected family members [153]. The mean age at presentation is 50 years (range 31-74) [173], but it has been reported in a 20 -year-old patient [167]. In more than half of the cases, the tumors are bilateral and/or multifocal [153, $173,174]$. Renal tumors encountered in BHD may have
Daccord/Nicod/Lazor 
different and sometimes mixed histologies with varying potential for malignancy, ranging from benign oncocytomas, observed in $5 \%$ of cases, to malignant clear cell renal carcinomas, accounting for $9 \%$ of BHD-associated renal tumors [173-175]. Chromophobe renal cell carcinoma and a mixed pattern of chromophobe renal cell carcinoma and oncocytoma, both associated with a low malignant potential, account for more than $70-80 \%$ of BHDassociated renal tumors, which differs from the large predominance of the clear cell histologic subtype observed in sporadic renal tumors $[167,173,175]$. AML are rare in BHD [165]. Renal cysts have frequently been reported in BHD patients, but they are also common in the general population, and it is not known whether an association between BHD and renal cysts exists $[126,161]$.

\section{Other Clinical Manifestations}

Other benign or malignant tumors have occasionally been reported in BHD, such as parotid oncocytomas [176], parathyroid adenomas [125, 177], lipomas [125, $126]$, breast cancer, melanoma, and others $[149,178]$, although no formal causal relationship to FLCN gene mutations has been established so far. An association between BHD and colorectal polyps or carcinoma has been suspected [122], but it was not confirmed by colonoscopic screening of $45 \mathrm{BHD}$ patients [153]. However, a recent study found a significantly higher risk of colorectal neoplasia in a subset of patients with BHD, suggesting a genotype-phenotype correlation [179].

\section{Imaging}

HRCT is the recommended imaging modality for the assessment of lung involvement in BHD. The typical HRCT feature is the presence of multiple bilateral pulmonary cysts with a normal surrounding parenchyma [44]. However, the mere presence of characteristic pulmonary cysts is not sufficient to establish the diagnosis with certainty [165]. The cysts can vary widely in size, shape, and number, but they are typically thin-walled and predominantly distributed in the basal, subpleural, or paramediastinal regions of the lung (Fig. 4b, c) [44, 180]. They can be round, oval, lentiform, or irregularly shaped, and they

Fig. 4. Birt-Hogg-Dubé syndrome. a Multiple fibrofolliculomas of the nose. $\mathbf{b}$ Chest computed tomography: a few pulmonary cysts of uneven distribution, size, and shape in the lung bases (arrows). c Chest computed tomography with frontal plane reconstruction: multiple cysts adjacent to blood vessels, fissures, and visceral pleura, with predominantly basal and paramediastinal locations (arrows).

Cystic Lung Disease in Genetic

Syndromes
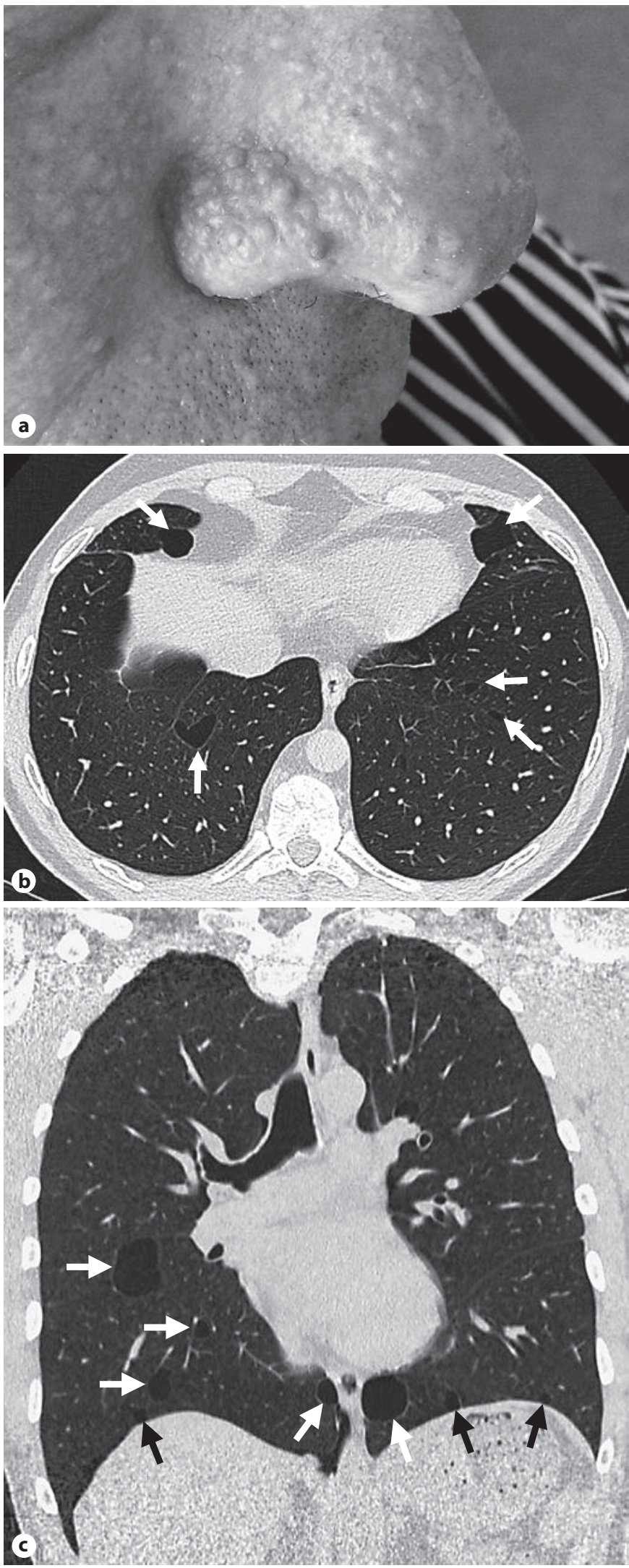

Respiration 
are generally surrounded by perceptible thin, uniform walls. Large cysts usually have a lobulated, multiseptate appearance [180]. The size of the cysts can range from a few millimeters to $2 \mathrm{~cm}$ or more, but the majority is below $1 \mathrm{~cm}$ in diameter [140]. They range in number from a few to more than $400[43,44,165]$, with fewer than 20 cysts in the majority of cases [180] and less than $30 \%$ of the lung volume involved [44]. A larger cyst size and a basal localization of the cysts are associated with an increased risk of spontaneous pneumothorax $[43,154,164]$.

The morphological aspects and distribution of the lung cysts helps in differentiating BHD from emphysema and other diffuse cystic lung diseases such as LAM. Large irregular cysts with a lobulated or multiseptate appearance, particularly if located in the subpleural lower lung fields, as well as cysts abutting or including the proximal portion of the lower pulmonary veins or arteries, are suggestive of BHD [165]. The basal and medial predominance of BHDassociated cysts contrasts with the apex-predominant distribution of dilated airspaces and blebs observed in smoking-related emphysema and primary spontaneous pneumothorax [148]. In comparison to LAM, pulmonary cysts in BHD are of larger size, lower number, and less circular shape and have a more predominant distribution at the lung bases and in paramediastinal locations [165]. Unlike in LAM, the number and size of lung cysts in BHD do not seem to increase significantly over time [44, 181]; however, the available data are scarce.

\section{Histopathology}

Based on the examination of ruptured cystic lesions of resected lung specimens following a spontaneous pneumothorax, the histological features of pulmonary cysts in BHD have been described as nonspecific and indistinguishable from those of emphysema, except for the predominantly basal location of the lesions [182]. However, the analysis of unruptured cysts provided some clues for the histological diagnosis of BHD. The inner surface of the cysts is lined by epithelial cells, without evidence of associated aberrant proliferation, atypical morphology, inflammation, or fibrosis $[137,183]$. The cysts are located near the interlobular septa and/or visceral pleura, and each cyst is merged in part with the interstitial stroma of the interlobular septum and/or pleura, and in part with the normal alveolar structures.

More recently, an analysis of 229 cysts from 50 patients with BHD confirmed the predominantly basal distribution of the cysts, and that they were surrounded by normal lung parenchyma without any evidence of neoplastic cell proliferation or inflammation [184]. The cysts were frequently intraparenchymal with no apparent communication with the airways, most often abutting the interlobular septa, and sometimes containing intracystic structures composed of interlobular septa. Together with the abnormal location of the cysts, these findings suggest that cystic lesions in BHD are clearly distinct from the apical centrilobular-predominant pattern of emphysema and subpleural blebs.

\section{Diagnosis}

BHD is a rare condition and is therefore likely to be underdiagnosed or misdiagnosed as primary spontaneous pneumothorax, emphysema, or another cystic lung disease such as LAM. Moreover, given its highly variable clinical expression, the diagnosis is often delayed by years [159]. Nevertheless, an early diagnosis is crucial to offer patients and their affected relatives regular screening for renal cancer.

Spontaneous pneumothorax is the most frequent manifestation leading to the diagnosis of BHD, although usually only after the second episode [159]. BHD is likely to be responsible for $5-10 \%$ of cases of apparent primary spontaneous pneumothorax [146, 185]. HRCT screening for BHD or another underlying diffuse cystic lung disease such as LAM or PLCH appeared cost-effective for patients presenting with apparent primary spontaneous pneumothorax, and should therefore be considered [159].

When BHD is suspected, a detailed personal and family history of skin lesions, pneumothorax, lung cysts, and renal tumors can provide important diagnostic clues. If present, they support the suspicion of the disease and should prompt further investigations. The patient should undergo a skin examination with punch biopsy if skin lesions are present, an abdominal CT or MRI as screening for renal tumors, a chest HRCT with review of the cysts' morphology and distribution by an expert radiologist, and pulmonary function testing [148]. Genetic counselling with testing for FLCN gene mutations should be offered to confirm the diagnosis and facilitate the screening of family members.

Confirmation of a BHD diagnosis relies on different combinations of clinical features and/or the identification of a FLCN germline mutation. Two diagnostic algorithms have been proposed, but they still await multidisciplinary validation (Table 3 ) [148, 149]. It is worth noting that a negative FLCN gene test result does not exclude the diagnosis. Regarding renal involvement, multifocal or bilateral renal cancer is very specific to $\mathrm{BHD}$, and a mixed chromophobe and oncocytic histology is almost pathognomonic of the syndrome.
12

Respiration

DOI: $10.1159 / 000485106$
Daccord/Nicod/Lazor 


\section{Management and Prognosis}

Management of BHD should focus on early diagnosis of the disease, identification of affected family members, early detection and treatment of renal tumors, and prevention of pneumothorax. Given the high prevalence of pulmonary cysts and renal tumors in BHD, screening for lung and kidney involvement is recommended in asymptomatic individuals with genetically confirmed disease.

There are currently no therapeutic options for BHDassociated cystic lung disease. Whether inhibition of the mTOR pathway could play a role in preventing cyst formation is unknown. Consequently, management of BHD primarily aims at preventing and treating pneumothorax [148]. Patients with BHD must be informed about the risk and symptoms of pneumothorax and encouraged to seek medical care in case of new or worsening dyspnea or chest pain. It seems wise to discourage patients from diving, but unreasonable to advise against air travel, regardless of the slightly increased risk of pneumothorax observed during and after a flight [158]. However, patients with an ongoing or recently treated pneumothorax should not travel by air. Given the high recurrence rate of pneumothorax, pleurodesis should be considered after the first episode of spontaneous pneumothorax [148]. As pulmonary function test results are usually normal and cystic involvement is unlikely to significantly impact lung function, regular follow-up with pulmonary function tests and chest HRCT is not recommended for most patients. In case of profusion of pulmonary cysts along with impaired lung function, periodic pulmonary function testing should be considered [148]. Although there is no evidence of a causal association between tobacco and the development of pulmonary cysts, pneumothorax, or lung functional decline, smoking should be discouraged. Pneumococcal vaccination and annual influenza vaccination are recommended.

All patients with BHD should be offered screening for renal tumors at the time of diagnosis or from 20 years of age [186]. If no tumor is detected on initial screening, lifelong surveillance is recommended with follow-up imaging every 3-4 years in order to identify tumors at an early stage. As renal ultrasound is not sensitive enough to detect small tumors [187] and the cumulative radiation exposure from repeated CT is prohibitive, MRI is the recommended imaging modality $[186,188]$. The majority of BHD-associated renal tumors have a low malignant potential, and the prognosis is usually favorable. As patients can develop several renal tumors during their lifetime, a delayed nephron-sparing strategy is favored to prevent metastatic spread in time but also to preserve as much
Table 3. Diagnostic criteria for BHD

Diagnostic criteria proposed by Menko et al. [149]

The patient should fulfill 1 major or 2 minor criteria for the diagnosis

\begin{tabular}{|c|c|}
\hline Major criteria & $\begin{array}{l}\text { - At least } 5 \text { fibrofolliculomas or trichodiscomas, } \\
\text { at least } 1 \text { histologically confirmed, of adult onset } \\
\text { - Pathogenic FLCN germline mutation }\end{array}$ \\
\hline Minor criteria & $\begin{array}{l}\text { - Multiple lung cysts: bilateral basally located } \\
\text { lung cysts with no other apparent cause, with or } \\
\text { without spontaneous primary pneumothorax } \\
\text { - Renal cancer: early onset ( }<50 \text { years) or } \\
\text { multifocal or bilateral renal cancer, or renal } \\
\text { cancer of mixed chromophobe and oncocytic } \\
\text { histology } \\
\text { - A 1st-degree relative with BHD }\end{array}$ \\
\hline
\end{tabular}

\section{Diagnostic criteria proposed by Gupta et al. [148]}

Definite - Characteristic or compatible lung HRCT and pulmonary skin biopsy positive for fibrofolliculoma or BHD trichodiscoma

- Characteristic or compatible lung HRCT and confirmed family history of BHD in 1st- or 2nd-degree family member

- Characteristic or compatible lung HRCT, and tissue confirmation or renal chromophobe adenoma or oncocytoma

- Characteristic or compatible lung HRCT, and tissue confirmation of genetic testing positive for $\mathrm{BHD}$

\section{Probable - Characteristic HRCT, exclusion of TSC}

pulmonary and LAM, and personal or family history of BHD pneumothorax

- Compatible HRCT, exclusion of TSC and

LAM, and any of the following:

- family or personal history of renal tumors

- skin angiofibroma

- renal angiomyolipoma

Possible - Compatible or characteristic HRCT

pulmonary

BHD

Characteristic lung HRCT findings: multiple thin-walled, round, elliptical, or lentiform, well-defined air-filled cysts, without internal structure, in a basilar, medial, and subpleural predominant distribution, with preserved or increased lung volume and no other significant pulmonary involvement (specifically, no interstitial lung disease). Compatible HRCT findings: thin-walled cysts without the more typical elliptical shape or subpleural distribution. $\mathrm{BHD}$, Birt-Hogg-Dubé syndrome; HRCT, high-resolution computed tomography; TSC, tuberous sclerosis complex; LAM, lymphangioleiomyomatosis. 
kidney function as possible $[186,188]$. In addition, prior surgical procedures can complicate subsequent resections and interfere with imaging interpretation. Therefore, once one or more tumors are detected, it is recommended to postpone surgery until the largest mass reaches $3 \mathrm{~cm}$ in diameter, with subsequent imaging intervals depending on the type, size, and growth rate of the lesions $[173,186,188]$. Cryotherapy and radiofrequency ablation are alternative nephron-sparing techniques if surgery is contraindicated. One Japanese patient with BHD and metastatic renal cancer was treated with everolimus, which, reportedly, exhibited a relatively long-term effect [189]. Further studies are needed to assess the efficacy of agents targeting the mTOR pathway in BHD-associated renal cancer.
Cutaneous manifestations of BHD are benign, and no treatment or follow-up is needed. The skins lesions can be removed surgically - or with laser therapy or curettage for cosmetic reasons, but they tend to recur [190-193]. A recent trial of topical sirolimus has shown no improvement with regard to the number and size of fibrofolliculomas in patients with BHD [194].

\section{Acknowledgements}

The authors acknowledge Nathalie Bacco for secretarial assistance.

\section{References}

1 Urban T, Lazor R, Lacronique J, Murris M, Labrune S, Valeyre D, Cordier JF: Pulmonary lymphangioleiomyomatosis: a study of $69 \mathrm{pa}-$ tients. Groupe d'Etudes et de Recherche sur les Maladies "Orphelines" Pulmonaires (GERM“O”P). Medicine (Baltimore) 1999; 78:321-337.

- Johnson SR, Tattersfield AE: Clinical experience of lymphangioleiomyomatosis in the UK. Thorax 2000;55:1052-1057.

-3 Harknett EC, Chang WYC, Byrnes S, Johnson J, Lazor R, Cohen MM, Gray B, Geiling S, Telford $\mathrm{H}$, Tattersfield AE, Hubbard RB, Johnson SR: Use of variability in national and regional data to estimate the prevalence of lymphangioleiomyomatosis. QJM 2011;104: 971-979.

4 Curatolo P, Bombardieri R, Jozwiak S: Tuberous sclerosis. Lancet 2008;372:657-668.

5 Northrup H, Krueger DA; International Tuberous Sclerosis Complex Consensus Group: Tuberous sclerosis complex diagnostic criteria update: recommendations of the 2012 International Tuberous Sclerosis Complex Consensus Conference. Pediatr Neurol 2013; 49:243-254.

-6 Krueger DA, Northrup H; International Tuberous Sclerosis Complex Consensus Group: Tuberous sclerosis complex surveillance and management: recommendations of the 2012 International Tuberous Sclerosis Complex Consensus Conference. Pediatr Neurol 2013; 49:255-265.

7 Seibert D, Hong CH, Takeuchi F, Olsen C, Hathaway O, Moss J, Darling TN: Recognition of tuberous sclerosis in adult women: delayed presentation with life-threatening consequences. Ann Intern Med 2011;154:806813.

-8 Johnson SR, Taveira-DaSilva AM, Moss J: Lymphangioleiomyomatosis. Clin Chest Med 2016;37:389-403.
-9 Lazor R, Valeyre D, Lacronique J, Wallaert B, Urban T, Cordier JF; Groupe d'Etudes et de Recherche sur les Maladies "Orphelines" Pulmonaires: Low initial KCO predicts rapid FEV1 decline in pulmonary lymphangioleiomyomatosis. Respir Med 2004;98:536-541.

10 Ryu JH, Moss J, Beck GJ, Lee JC, Brown KK, Chapman JT, Finlay GA, Olson EJ, Ruoss SJ, Maurer JR, Raffin TA, Peavy HH, McCarthy K, Taveira-Dasilva A, McCormack FX, Avila NA, Decastro RM, Jacobs SS, Stylianou M, Fanburg BL; NHLBI LAM Registry Group: The NHLBI lymphangioleiomyomatosis registry: characteristics of 230 patients at enrollment. Am J Respir Crit Care Med 2006;173: 105-111.

11 Taveira-DaSilva AM, Hedin C, Stylianou MP, Travis WD, Matsui K, Ferrans VJ, Moss J: Reversible airflow obstruction, proliferation of abnormal smooth muscle cells, and impairment of gas exchange as predictors of outcome in lymphangioleiomyomatosis. Am J Respir Crit Care Med 2001;164:1072-1076.

$\checkmark 12$ Johnson SR, Whale CI, Hubbard RB, Lewis SA, Tattersfield AE: Survival and disease progression in UK patients with lymphangioleiomyomatosis. Thorax 2004;59:800-803.

13 Oprescu N, McCormack FX, Byrnes S, Kinder BW: Clinical predictors of mortality and cause of death in lymphangioleiomyomatosis: a population-based registry. Lung 2013;191: $35-42$.

14 Taveira-DaSilva AM, Hathaway OM, Sachdev V, Shizukuda Y, Birdsall CW, Moss J: Pulmonary artery pressure in lymphangioleiomyomatosis: an echocardiographic study. Chest 2007;132:1573-1578.
15 Freitas CSG, Baldi BG, Jardim C, Araujo MS, Sobral JB, Heiden GI, Kairalla RA, Souza R, Carvalho CRR: Pulmonary hypertension in lymphangioleiomyomatosis: prevalence, severity and the role of carbon monoxide diffusion capacity as a screening method. Orphanet J Rare Dis 2017;12:74.

16 Glasgow CG, Avila NA, Lin JP, Stylianou MP, Moss J: Serum vascular endothelial growth factor-D levels in patients with lymphangioleiomyomatosis reflect lymphatic involvement. Chest 2009;135:1293-1300.

17 Cudzilo CJ, Szczesniak RD, Brody AS, Rattan MS, Krueger DA, Bissler JJ, Franz DN, McCormack FX, Young LR: Lymphangioleiomyomatosis screening in women with tuberous sclerosis. Chest 2013;144:578-585.

18 Young L, Lee HS, Inoue Y, Moss J, Singer LG, Strange C, Nakata K, Barker AF, Chapman JT, Brantly ML, Stocks JM, Brown KK, Lynch JP 3rd, Goldberg HJ, Downey GP, Swigris JJ, Taveira-DaSilva AM, Krischer JP, Trapnell BC, McCormack FX; MILES Trial Group: Serum VEGF-D concentration as a biomarker of lymphangioleiomyomatosis severity and treatment response: a prospective analysis of the Multicenter International Lymphangioleiomyomatosis Efficacy of Sirolimus (MILES) trial. Lancet Respir Med 2013;1:445-452.

19 McCormack FX, Gupta N, Finlay GR, Young LR, Taveira-DaSilva AM, Glasgow CG, et al; ATS/JTS Committee on Lymphangioleiomyomatosis: Official American Thoracic Society/Japanese Respiratory Society clinical practice guidelines: lymphangioleiomyomatosis diagnosis and management. Am J Respir Crit Care Med 2016;194:748-761.

20 Yeoh ZW, Navaratnam V, Bhatt R, McCafferty I, Hubbard RB, Johnson SR: Natural history of angiomyolipoma in lymphangioleiomyomatosis: implications for screening and surveillance. Orphanet J Rare Dis 2014;9:151. 
-21 Taveira-DaSilva AM, Jones AM, Julien-Williams P, Yao J, Stylianou M, Moss J: Severity and outcome of cystic lung disease in women with tuberous sclerosis complex. Eur Respir J 2015;45:171-180.

22 Aubry MC, Myers JL, Ryu JH, Henske EP, Logginidou H, Jalal SM, Tazelaar HD: Pulmonary lymphangioleiomyomatosis in a man. Am J Respir Crit Care Med 2000;162:749752.

23 Schiavina M, Di Scioscio V, Contini P, Cavazza A, Fabiani A, Barberis M, Bini A, Altimari A, Cooke RM, Grigioni WF, D'Errico-Grigioni A: Pulmonary lymphangioleiomyomatosis in a karyotypically normal man without tuberous sclerosis complex. Am J Respir Crit Care Med 2007;176:96-98.

-24 Adriaensen ME, Schaefer-Prokop CM, Duyndam DA, Zonnenberg BA, Prokop M: Radiological evidence of lymphangioleiomyomatosis in female and male patients with tuberous sclerosis complex. Clin Radiol 2011;66:625628.

-25 Ryu JH, Sykes AM, Lee AS, Burger CD: Cystic lung disease is not uncommon in men with tuberous sclerosis complex. Respir Med 2012; 106:1586-1590.

26 Moss J, DeCastro R, Patronas NJ, TaveiraDaSilva A: Meningiomas in lymphangioleiomyomatosis. JAMA 2001;286:1879-1881.

-27 Cottin V, Vukusic S, Jouanneau E, Lazor R, Cordier JF: Should patients with lymphangioleiomyomatosis undergo screening for meningioma? Eur Respir J 2004;24:888-889.

28 McCormack FX, Travis WD, Colby TV, Henske EP, Moss J: Lymphangioleiomyomatosis: calling it what it is: a low-grade, destructive, metastasizing neoplasm. Am J Respir Crit Care Med 2012;186:1210-1212.

-29 Thway K, Fisher C: PEComa: morphology and genetics of a complex tumor family. Ann Diagn Pathol 2015;19:359-368.

- 30 Matsumoto Y, Horiba K, Usuki J, Chu SC, Ferrans VJ, Moss J: Markers of cell proliferation and expression of melanosomal antigen in lymphangioleiomyomatosis. Am J Respir Cell Mol Biol 1999;21:327-336.

- 31 Hayashi T, Fleming MV, Stetler-Stevenson WG, Liotta LA, Moss J, Ferrans VJ, Travis WD: Immunohistochemical study of matrix metalloproteinases (MMPs) and their tissue inhibitors (TIMPs) in pulmonary lymphangioleiomyomatosis (LAM). Hum Pathol 1997; 28:1071-1078.

- 32 Seyama K, Kumasaka T, Souma S, Sato T, Kurihara M, Mitani K, Tominaga S, Fukuchi $\mathrm{Y}$ : Vascular endothelial growth factor-D is increased in serum of patients with lymphangioleiomyomatosis. Lymphat Res Biol 2006;4: 143-152.

- 33 Issaka RB, Oommen S, Gupta SK, Liu G, Myers JL, Ryu JH, Vlahakis NE: Vascular endothelial growth factors $\mathrm{C}$ and $\mathrm{D}$ induces proliferation of lymphangioleiomyomatosis cells through autocrine crosstalk with endothelium. Am J Pathol 2009;175:1410-1420.
34 Smolarek TA, Wessner LL, McCormack FX, Mylet JC, Menon AG, Henske EP: Evidence that lymphangiomyomatosis is caused by TSC2 mutations: chromosome 16p13 loss of heterozygosity in angiomyolipomas and lymph nodes from women with lymphangiomyomatosis. Am J Hum Genet 1998;62:810815.

35 Carsillo T, Astrinidis A, Henske EP: Mutations in the tuberous sclerosis complex gene TSC2 are a cause of sporadic pulmonary lymphangioleiomyomatosis. Proc Natl Acad Sci USA 2000;97:6085-6090.

36 Barnes EA, Kenerson HL, Mak BC, Yeung RS: The loss of tuberin promotes cell invasion through the $\beta$-catenin pathway. Am J Respir Cell Mol Biol 2010;43:617-627.

37 Flavin RJ, Cook J, Fiorentino M, Bailey D, Brown M, Loda MF: $\beta$-Catenin is a useful adjunct immunohistochemical marker for the diagnosis of pulmonary lymphangioleiomyomatosis. Am J Clin Pathol 2011;135:776-782.

38 Pacheco-Rodriguez G, Steagall WK, Crooks DM, Stevens LA, Hashimoto H, Li S, Wang JA, Darling TN, Moss J: TSC2 loss in lymphangioleiomyomatosis cells correlated with expression of CD44v6, a molecular determinant of metastasis. Cancer Res 2007;67:1057310581.

39 Li S, Takeuchi F, Wang JA, Fuller C, PachecoRodriguez G, Moss J, Darling TN: MCP-1 overexpressed in tuberous sclerosis lesions acts as a paracrine factor for tumor development. J Exp Med 2005;202:617-624.

40 Pacheco-Rodriguez G, Kumaki F, Steagall WK, Zhang Y, Ikeda Y, Lin JP, Billings EM, Moss J: Chemokine-enhanced chemotaxis of lymphangioleiomyomatosis cells with mutations in the tumor suppressor TSC2 gene. J Immunol 2009;182:1270-1277.

41 Mitani K, Kumasaka T, Takemura H, Hayashi T, Gunji Y, Kunogi M, Akiyoshi T, Takahashi K, Suda K, Seyama K: Cytologic, immunocytochemical and ultrastructural characterization of lymphangioleiomyomatosis cell clusters in chylous effusions of patients with lymphangioleiomyomatosis. Acta Cytol 2009; 53:402-409.

42 Seaman DM, Meyer CA, Gilman MD, McCormack FX: Diffuse cystic lung disease at high-resolution CT. AJR Am J Roentgenol 2011;196:1305-1311.

43 Toro JR, Pautler SE, Stewart L, Glenn GM, Weinreich M, Toure O, Wei MH, Schmidt LS, Davis L, Zbar B, Choyke P, Steinberg SM, Nguyen DM, Linehan WM: Lung cysts, spontaneous pneumothorax, and genetic associations in 89 families with Birt-Hogg-Dubé syndrome. Am J Respir Crit Care Med 2007;175: 1044-1053.

44 Tobino K, Gunji Y, Kurihara M, Kunogi M, Koike K, Tomiyama N, Johkoh T, Kodama Y, Iwakami S, Kikkawa M, Takahashi K, Seyama $\mathrm{K}$ : Characteristics of pulmonary cysts in BirtHogg-Dubé syndrome: thin-section CT findings of the chest in 12 patients. Eur J Radiol 2011;77:403-409.
5 Castoldi MC, Verrioli A, De Juli E, Vanzulli A: Pulmonary Langerhans cell histiocytosis: the many faces of presentation at initial CT scan. Insights Imaging 2014;5:483-492.

46 Colombat M, Stern M, Groussard O, Droz D, Brauner M, Valeyre D, Mal H, Taillé C, Monnet I, Fournier M, Herson S, Danel C: Pulmonary cystic disorder related to light chain deposition disease. Am J Respir Crit Care Med 2006; 173:777-780.

47 Franz DN, Brody A, Meyer C, Leonard J, Chuck G, Dabora S, Sethuraman G, Colby TV, Kwiatkowski DJ, McCormack FX: Mutational and radiographic analysis of pulmonary disease consistent with lymphangioleiomyomatosis and micronodular pneumocyte hyperplasia in women with tuberous sclerosis. Am J Respir Crit Care Med 2001; 164:661668.

48 Avila NA, Kelly JA, Chu SC, Dwyer AJ, Moss $\mathrm{J}$ : Lymphangioleiomyomatosis: abdominopelvic CT and US findings. Radiology 2000; 216:147-153.

49 Avila NA, Dwyer AJ, Moss J: Imaging features of lymphangioleiomyomatosis: diagnostic pitfalls. AJR Am J Roentgenol 2011;196:982986.

50 Avila NA, Bechtle J, Dwyer AJ, Ferrans VJ, Moss J: Lymphangioleiomyomatosis: CT of diurnal variation of lymphangioleiomyomas. Radiology 2001;221:415-421.

51 Taveira-DaSilva AM, Jones AM, Julien-Williams P, Shawker T, Glasgow CG, Stylianou M, Moss J: Effect of fasting on the size of lymphangioleiomyomas in patients with lymphangioleiomyomatosis. Chest 2015;148: 1027-1033.

52 European Chromosome 16 Tuberous Sclerosis Consortium: Identification and characterization of the tuberous sclerosis gene on chromosome 16. Cell 1993;75:1305-1315.

53 van Slegtenhorst M, de Hoogt R, Hermans C, Nellist M, Janssen B, Verhoef $S$, et al: Identification of the tuberous sclerosis gene TSC1 on chromosome 9q34. Science 1997;277:805808.

54 Dabora SL, Jozwiak S, Franz DN, Roberts PS, Nieto A, Chung J, Choy YS, Reeve MP, Thiele E, Egelhoff JC, Kasprzyk-Obara J, DomanskaPakiela D, Kwiatkowski DJ: Mutational analysis in a cohort of 224 tuberous sclerosis patients indicates increased severity of TSC2, compared with TSC1, disease in multiple organs. Am J Hum Genet 2001;68:64-80.

55 Knudson AG: Two genetic hits (more or less) to cancer. Nat Rev Cancer 2001;1:157-162.

56 Montagne J, Radimerski T, Thomas G: Insulin signaling: lessons from the Drosophila tuberous sclerosis complex, a tumor suppressor. Sci STKE 2001;2001:pe36.

57 Henske EP, McCormack FX: Lymphangioleiomyomatosis - a wolf in sheep's clothing. J Clin Invest 2012;122:3807-3816.

58 Krymskaya VP, McCormack FX: Lymphangioleiomyomatosis: a monogenic model of malignancy. Annu Rev Med 2017;68:69-83. 
59 Hartman TR, Nicolas E, Klein-Szanto A, AlSaleem T, Cash TP, Simon MC, Henske EP: The role of the Birt-Hogg-Dubé protein in mTOR activation and renal tumorigenesis. Oncogene 2009;28:1594-1604.

-60 Tsun ZY, Bar-Peled L, Chantranupong L, Zoncu R, Wang T, Kim C, Spooner E, Sabatini DM: The folliculin tumor suppressor is a GAP for the RagC/D GTPases that signal amino acid levels to mTORC1. Mol Cell 2013;52: 495-505.

-61 Yano S: Exacerbation of pulmonary lymphangioleiomyomatosis by exogenous oestrogen used for infertility treatment. Thorax 2002;57: 1085-1086.

-62 Taveira-DaSilva AM, Stylianou MP, Hedin CJ, Hathaway O, Moss J: Decline in lung function in patients with lymphangioleiomyomatosis treated with or without progesterone. Chest 2004;126:1867-1874.

-63 Yu J, Astrinidis A, Howard S, Henske EP: Estradiol and tamoxifen stimulate LAM-associated angiomyolipoma cell growth and activate both genomic and nongenomic signaling pathways. Am J Physiol Lung Cell Mol Physiol 2004;286:L694-L700.

64 Glassberg MK, Elliot SJ, Fritz J, Catanuto P, Potier M, Donahue R, Stetler-Stevenson W, Karl M: Activation of the estrogen receptor contributes to the progression of pulmonary lymphangioleiomyomatosis via matrix metalloproteinase-induced cell invasiveness. J Clin Endocrinol Metab 2008;93:1625-1633.

- 65 Yu JJ, Robb VA, Morrison TA, Ariazi EA, Karbowniczek M, Astrinidis A, Wang C, Hernandez-Cuebas L, Seeholzer LF, Nicolas E, Hensley H, Jordan VC, Walker CL, Henske EP: Estrogen promotes the survival and pulmonary metastasis of tuberin-null cells. Proc Natl Acad Sci USA 2009;106:2635-2640.

-66 Hayashi T, Kumasaka T, Mitani K, Terao Y, Watanabe M, Oide T, Nakatani Y, Hebisawa A, Konno R, Takahashi K, Yao T, Seyama K: Prevalence of uterine and adnexal involvement in pulmonary lymphangioleiomyomatosis: a clinicopathologic study of 10 patients. Am J Surg Pathol 2011;35:1776-1785.

-67 Kumasaka T, Seyama K, Mitani K, Sato T, Souma S, Kondo T, Hayashi S, Minami M, Uekusa T, Fukuchi Y, Suda K: Lymphangiogenesis in lymphangioleiomyomatosis: its implication in the progression of lymphangioleiomyomatosis. Am J Surg Pathol 2004;28: 1007-1016.

68 Bittmann I, Rolf B, Amann G, Löhrs U: Recurrence of lymphangioleiomyomatosis after single lung transplantation: new insights into pathogenesis. Hum Pathol 2003;34:95-98.

-69 Karbowniczek M, Astrinidis A, Balsara BR, Testa JR, Lium JH, Colby TV, McCormack FX, Henske EP: Recurrent lymphangiomyomatosis after transplantation: genetic analyses reveal a metastatic mechanism. Am J Respir Crit Care Med 2003;167:976-982.

-70 Crooks DM, Pacheco-Rodriguez G, DeCastro RM, McCoy JP Jr, Wang JA, Kumaki F, Darling T, Moss J: Molecular and genetic analysis of disseminated neoplastic cells in lymphangioleiomyomatosis. Proc Natl Acad Sci USA 2004; 101:17462-17467.

-71 Cai X, Pacheco-Rodriguez G, Fan QY, Haughey M, Samsel L, El-Chemaly S, Wu HP, McCoy JP, Steagall WK, Lin JP, Darling TN, Moss J: Phenotypic characterization of disseminated cells with TSC2 loss of heterozygosity in patients with lymphangioleiomyomatosis. Am J Respir Crit Care Med 2010;182:1410-1418.

72 Steagall WK, Zhang L, Cai X, Pacheco-Rodriguez G, Moss J: Genetic heterogeneity of circulating cells from patients with lymphangioleiomyomatosis with and without lung transplantation. Am J Respir Crit Care Med 2015;191:854-856.

73 Matsui K, Takeda K, Yu ZX, Travis WD, Moss J, Ferrans VJ: Role for activation of matrix metalloproteinases in the pathogenesis of pulmonary lymphangioleiomyomatosis. Arch Pathol Lab Med 2000;124:267-275.

74 Johnson SR, Cordier JF, Lazor R, Cottin V, Costabel U, Harari S, Reynaud-Gaubert M, Boehler A, Brauner M, Popper H, Bonetti F, Kingswood C; Review Panel of the ERS LAM Task Force: European Respiratory Society guidelines for the diagnosis and management of lymphangioleiomyomatosis. Eur Respir J 2010;35:14-26.

75 Avila NA, Dwyer AJ, Rabel A, Darling T, Hong $\mathrm{CH}$, Moss J: CT of sclerotic bone lesions: imaging features differentiating tuberous sclerosis complex with lymphangioleiomyomatosis from sporadic lymphangioleiomymatosis. Radiology 2010;254:851-857.

76 Brugarolas JB, Vazquez F, Reddy A, Sellers WR, Kaelin WG Jr: TSC2 regulates VEGF through mTOR-dependent and -independent pathways. Cancer Cell 2003;4:147-158.

77 Young LR, Inoue Y, McCormack FX: Diagnostic potential of serum VEGF-D for lymphangioleiomyomatosis. N Engl J Med 2008;358:199-200.

78 Young LR, Vandyke R, Gulleman PM, Inoue Y, Brown KK, Schmidt LS, Linehan WM, Hajjar F, Kinder BW, Trapnell BC, Bissler JJ, Franz DN, McCormack FX: Serum vascular endothelial growth factor-D prospectively distinguishes lymphangioleiomyomatosis from other diseases. Chest 2010;138:674-681.

79 Chang WY, Cane JL, Blakey JD, Kumaran M, Pointon KS, Johnson SR: Clinical utility of diagnostic guidelines and putative biomarkers in lymphangioleiomyomatosis. Respir Res 2012;13:34

80 Harari S, Torre O, Cassandro R, TaveiraDaSilva AM, Moss J: Bronchoscopic diagnosis of Langerhans cell histiocytosis and lymphangioleiomyomatosis. Respir Med 2012;106:1286-1292.

- 81 Meraj R, Wikenheiser-Brokamp KA, Young LR, Byrnes S, McCormack FX: Utility of transbronchial biopsy in the diagnosis of lymphangioleiomyomatosis. Front Med 2012;6:395-405.

82 Koba T, Arai T, Kitaichi M, Kasai T, Hirose M, Tachibana K, Sugimoto C, Akira M, Hayashi S, Inoue Y: Efficacy and safety of transbronchial lung biopsy for the diagnosis of lymphangioleiomyomatosis: a report of 24 consecutive patients. Respirology 2017, Epub ahead of print.

-83 Fruchter O, Fridel L, El Raouf BA, AbdelRahman N, Rosengarten D, Kramer MR: Histological diagnosis of interstitial lung diseases by cryo-transbronchial biopsy. Respirology 2014;19:683-688.

84 Radzikowska E, Jaguś P, Sobiecka M, Chorostowska-Wynimko J, Wiatr E, Kuś J, Roszkowski-Śliż K: Correlation of serum vascular endothelial growth factor-D concentration with clinical presentation and course of lymphangioleiomyomatosis. Respir Med 2015;109:1469-1475.

85 Taveira-DaSilva AM, Jones AM, Julien-Williams P, Stylianou M, Moss J: Long-term effect of sirolimus on serum vascular endothelial growth factor D levels in patients with lymphangioleiomyomatosis. Chest 2017, Epub ahead of print.

86 Araujo MS, Baldi BG, Freitas CS, Albuquerque AL, Marques da Silva CC, Kairalla RA, Carvalho CR, Carvalho CR: Pulmonary rehabilitation in lymphangioleiomyomatosis: a controlled clinical trial. Eur Respir J 2016;47:1452-1460.

87 Taveira-DaSilva AM, Steagall WK, Rabel A, Hathaway O, Harari S, Cassandro R, Stylianou M, Moss J: Reversible airflow obstruction in lymphangioleiomyomatosis. Chest 2009;136:1596-1603.

88 Taveira-DaSilva AM, Stylianou MP, Hedin CJ, Hathaway O, Moss J: Bone mineral density in lymphangioleiomyomatosis. Am J Respir Crit Care Med 2005;171:61-67.

89 Pollock-BarZiv S, Cohen MM, Downey GP, Johnson SR, Sullivan E, McCormack FX: Air travel in women with lymphangioleiomyomatosis. Thorax 2007;62:176-180.

90 Taveira-DaSilva AM, Burstein D, Hathaway OM, Fontana JR, Gochuico BR, Avila NA, Moss J: Pneumothorax after air travel in lymphangioleiomyomatosis, idiopathic pulmonary fibrosis, and sarcoidosis. Chest 2009; 136:665-670.

91 Cohen MM, Freyer AM, Johnson SR: Pregnancy experiences among women with lymphangioleiomyomatosis. Respir Med 2009; 103:766-772.

92 Almoosa KF, Ryu JH, Mendez J, Huggins JT, Young LR, Sullivan EJ, Maurer J, McCormack FX, Sahn SA: Management of pneumothorax in lymphangioleiomyomatosis: effects on recurrence and lung transplantation complications. Chest 2006;129:1274-1281.

93 Kurihara M, Mizobuchi T, Kataoka H, Sato T, Kumasaka T, Ebana H, Yamanaka S, Endo R, Miyahashira S, Shinya N, Seyama K: A total pleural covering for lymphangioleiomyomatosis prevents pneumothorax recurrence. PLoS One 2016;11:e0163637.

94 Bissler JJ, McCormack FX, Young LR, Elwing JM, Chuck G, Leonard JM, Schmithorst VJ, Laor T, Brody AS, Bean J, Salisbury S, Franz $\mathrm{DN}$ : Sirolimus for angiomyolipoma in tuberous sclerosis complex or lymphangioleiomyomatosis. N Engl J Med 2008;358:140-151. 
95 Taveira-DaSilva AM, Hathaway O, Stylianou M, Moss J: Changes in lung function and chylous effusions in patients with lymphangioleiomyomatosis treated with sirolimus. Ann Intern Med 2011;154:797805.

\$6 Neurohr C, Hoffmann AL, Huppmann P, Herrera VA, Ihle F, Leuschner S, von Wulffen W, Meis T, Baezner C, Leuchte H, Baumgartner R, Zimmermann G, Behr J: Is sirolimus a therapeutic option for patients with progressive pulmonary lymphangioleiomyomatosis? Respir Res 2011;12:66.

-97 McCormack FX, Inoue Y, Moss J, Singer LG, Strange C, Nakata K, Barker AF, Chapman JT, Brantly ML, Stocks JM, Brown KK, Lynch JP 3rd, Goldberg HJ, Young LR, Kinder BW, Downey GP, Sullivan EJ, Colby TV, McKay RT, Cohen MM, Korbee L, Taveira-DaSilva AM, Lee HS, Krischer JP, Trapnell BC: Efficacy and safety of sirolimus in lymphangioleiomyomatosis. $\mathrm{N}$ Engl J Med 2011;364:1595-1606.

$\$ 98$ Takada T, Mikami A, Kitamura N, Seyama K, Inoue Y, Nagai K, Suzuki M, Moriyama H, Akasaka K, Tazawa R, Hirai T, Mishima M, Hayashida M, Hirose M, Sugimoto C, Arai T, Hattori N, Watanabe K, Tamada T, Yoshizawa H, Akazawa K, Tanaka T, Yagi K, Young LR, McCormack FX, Nakata K: Efficacy and safety of long-term sirolimus therapy for Asian patients with lymphangioleiomyomatosis. Ann Am Thorac Soc 2016;13: 1912-1922.

-99 Bee J, Fuller S, Miller S, Johnson SR: Lung function response and side effects to rapamycin for lymphangioleiomyomatosis: a prospective national cohort study. Thorax 2017, Epub ahead of print.

100 Ando K, Kurihara M, Kataoka H, Ueyama M, Togo S, Sato T, Doi T, Iwakami S, Takahashi K, Seyama K, Mikami M: Efficacy and safety of low-dose sirolimus for treatment of lymphangioleiomyomatosis. Respir Investig 2013;51:175-183.

-101 Goldberg HJ, Harari S, Cottin V, Rosas IO, Peters E, Biswal S, Cheng Y, Khindri S, Kovarik JM, Ma S, McCormack FX, Henske EP: Everolimus for the treatment of lymphangioleiomyomatosis: a phase II study. Eur Respir J 2015;46:783-794.

102 Johnson SR, Tattersfield AE: Decline in lung function in lymphangioleiomyomatosis: relation to menopause and progesterone treatment. Am J Respir Crit Care Med 1999;160: 628-633.

103 Moses MA, Harper J, Folkman J: Doxycycline treatment for lymphangioleiomyomatosis with urinary monitoring for MMPs. N Engl J Med 2006;354:2621-2622.

104 Chang WY, Cane JL, Kumaran M, Lewis S, Tattersfield AE, Johnson SR: A 2-year randomised placebo-controlled trial of doxycycline for lymphangioleiomyomatosis. Eur Respir J 2014;43:1114-1123.

105 El-Chemaly S, Taveira-DaSilva A, Goldberg HJ, Peters E, Haughey M, Bienfang D, Jones
AM, Julien-Williams P, Cui Y, Villalba JA, Bagwe S, Maurer R, Rosas IO, Moss J, Henske EP: Sirolimus and autophagy inhibition in lymphangioleiomyomatosis: results of a phase I clinical trial. Chest 2017;151:13021310.

106 Lu C, Lee HS, Pappas GP, Dilling DF, Burger CD, Shifren A, Veeraraghavan S, Chapman JT, Parambil J, Ruoss SJ, Young LR, Hammes SR, Kopras EJ, Roads T, Krischer JP, McCormack FX; Trial of an Aromatase Inhibitor in Lymphangioleiomyomatosis Group: A phase II clinical trial of an aromatase inhibitor for postmenopausal women with lymphangioleiomyomatosis. Ann Am Thorac Soc 2017;14:919-928.

107 Boehler A, Speich R, Russi EW, Weder W: Lung transplantation for lymphangioleiomyomatosis. N Engl J Med 1996;335:12751280.

108 Kpodonu J, Massad MG, Chaer RA, Caines A, Evans A, Snow NJ, Geha AS: The US experience with lung transplantation for pulmonary lymphangioleiomyomatosis. J Heart Lung Transplant 2005;24:1247-1253.

109 Reynaud-Gaubert M, Mornex JF, Mal H, Treilhaud M, Dromer C, Quétant S, LeroyLadurie F, Guillemain R, Philit F, Dauriat G, Grenet D, Stern M: Lung transplantation for lymphangioleiomyomatosis: the French experience. Transplantation 2008;86:515-520.

-110 Benden C, Rea F, Behr J, Corris PA, Reynaud-Gaubert M, Stern M, Speich R, Boehler A: Lung transplantation for lymphangioleiomyomatosis: the European experience. J Heart Lung Transplant 2009;28:1-7.

-111 Ando K, Okada Y, Akiba M, Kondo T, Kawamura T, Okumura M, Chen F, Date H, Shiraishi T, Iwasaki A, Yamasaki N, Nagayasu T, Chida M, Inoue Y, Hirai T, Seyama K, Mishima M; Respiratory Failure Research Group of the Japanese Ministry of Health, Labour, and Welfare: Lung transplantation for lymphangioleiomyomatosis in Japan. PLoS One 2016;11:e0146749.

112 King-Biggs MB, Dunitz JM, Park SJ, Kay Savik S, Hertz MI: Airway anastomotic dehiscence associated with use of sirolimus immediately after lung transplantation. Transplantation 2003;75:1437-1443.

113 Groetzner J, Kur F, Spelsberg F, Behr J, Frey L, Bittmann I, Vogeser M, Ueberfuhr P, Meiser B, Hatz R, Reichart B; Munich Lung Transplant Group: Airway anastomosis complications in de novo lung transplantation with sirolimus-based immunosuppression. J Heart Lung Transplant 2004;23:632638.

114 Ohara T, Oto T, Miyoshi K, Tao H, Yamane M, Toyooka S, Okazaki M, Date H, Sano Y: Sirolimus ameliorated post lung transplant chylothorax in lymphangioleiomyomatosis. Ann Thorac Surg 2008;86:e7-e8.

115 Morton JM, McLean C, Booth SS, Snell GI, Whitford HM: Regression of pulmonary lymphangioleiomyomatosis (PLAM)-associated retroperitoneal angiomyolipoma post-lung transplantation with rapamycin treatment. J Heart Lung Transplant 2008;27: 462-465.

116 Chen F, Omasa M, Kondo N, Fujinaga T, Shoji T, Sakai H, Bando T: Sirolimus treatment for recurrent lymphangioleiomyomatosis after lung transplantation. Ann Thorac Surg 2009;87:e6-e7.

117 Ito T, Suno M, Sakamoto K, Yoshizaki Y, Yamamoto K, Nakanishi R, Hirano Y, Irie M, Kurosaki T, Otani S, Yamane M, Sugimoto S, Miyoshi K, Oto T: Therapeutic effect of sirolimus for lymphangioleiomyomatosis remaining in the abdominopelvic region after lung transplantation: a case report. Transplant Proc 2016;48:271-274.

-118 Davies DM, Johnson SR, Tattersfield AE, Kingswood JC, Cox JA, McCartney DL, Doyle T, Elmslie F, Saggar A, de Vries PJ, Sampson JR: Sirolimus therapy in tuberous sclerosis or sporadic lymphangioleiomyomatosis. N Engl J Med 2008;358:200-203.

119 Bissler JJ, Kingswood JC, Radzikowska E, Zonnenberg BA, Belousova E, Frost MD, Sauter M, Brakemeier S, de Vries PJ, Berkowitz N, Voi M, Peyrard S, Budde K: Everolimus long-term use in patients with tuberous sclerosis complex: four-year update of the EXIST-2 study. PLoS One 2017;12:e0180939.

120 Bissler JJ, Kingswood JC, Radzikowska E, Zonnenberg BA, Frost M, Belousova E, Sauter M, Nonomura N, Brakemeier S, de Vries PJ, Whittemore VH, Chen D, Sahmoud T, Shah G, Lincy J, Lebwohl D, Budde K: Everolimus for angiomyolipoma associated with tuberous sclerosis complex or sporadic lymphangioleiomyomatosis (EXIST-2): a multicentre, randomised, double-blind, placebo-controlled trial. Lancet 2013;381: 817-824.

121 Birt AR, Hogg GR, Dubé WJ: Hereditary multiple fibrofolliculomas with trichodiscomas and acrochordons. Arch Dermatol 1977;113:1674-1677.

122 Hornstein OP, Knickenberg M: Perifollicular fibromatosis cutis with polyps of the colon - a cutaneo-intestinal syndrome sui generis. Arch Dermatol Res 1975;253:161175.

123 Binet O, Audefray D, Beltzer-Garelly E, Gauchy O, Cesarini JP: Haber's syndrome. First French family (2 cases) (in French). Ann Dermatol Venereol 1986;113:43-50.

124 Roth JS, Rabinowitz AD, Benson M, Grossman ME: Bilateral renal cell carcinoma in the Birt-Hogg-Dubé syndrome. J Am Acad Dermatol 1993;29:1055-1056.

125 Chung JY, Ramos-Caro FA, Beers B, Ford MJ, Flowers F: Multiple lipomas, angiolipomas, and parathyroid adenomas in a patient with Birt-Hogg-Dubé syndrome. Int J Dermatol 1996;35:365-367.

126 Toro JR, Glenn G, Duray P, Darling T, Weirich G, Zbar B, Linehan M, Turner ML: BirtHogg-Dubé syndrome: a novel marker of kidney neoplasia. Arch Dermatol 1999;135: 1195-1202. 
127 Khoo SK, Bradley M, Wong FK, Hedblad MA, Nordenskjöld M, Teh BT: Birt-HoggDubé syndrome: mapping of a novel hereditary neoplasia gene to chromosome $17 \mathrm{p} 12$ q11.2. Oncogene 2001;20:5239-5242.

128 Schmidt LS, Warren MB, Nickerson ML, Weirich G, Matrosova V, Toro JR, Turner ML, Duray P, Merino M, Hewitt S, Pavlovich CP, Glenn G, Greenberg CR, Linehan WM, Zbar B: Birt-Hogg-Dubé syndrome, a genodermatosis associated with spontaneous pneumothorax and kidney neoplasia, maps to chromosome 17p11.2. Am J Hum Genet 2001;69:876-882.

129 Nickerson ML, Warren MB, Toro JR, Matrosova V, Glenn G, Turner ML, Duray P, Merino M, Choyke P, Pavlovich CP, Sharma N, Walther M, Munroe D, Hill R, Maher E, Greenberg C, Lerman MI, Linehan WM, Zbar B, Schmidt LS: Mutations in a novel gene lead to kidney tumors, lung wall defects, and benign tumors of the hair follicle in patients with the Birt-Hogg-Dubé syndrome. Cancer Cell 2002;2:157-164.

130 Cottin V, Cordier JF, Khouatra C, Giraud S, Lazor R: Multiple cystic lung diseases; in Cottin V, Cordier JF, Richeldi L (eds): Orphan Lung Diseases: A Clinical Guide to Rare Lung Disease. Springer, 2015, pp 253-270.

131 Schmidt LS, Linehan WM: FLCN: the causative gene for Birt-Hogg-Dubé syndrome. Gene 2018;640:28-42.

132 Schmidt LS, Nickerson ML, Warren MB, Glenn GM, Toro JR, Merino MJ, Turner ML, Choyke PL, Sharma N, Peterson J, Morrison P, Maher ER, Walther MM, Zbar B, Linehan WM: Germline BHD-mutation spectrum and phenotype analysis of a large cohort of families with Birt-Hogg-Dubé syndrome. Am J Hum Genet 2005;76:1023-1033.

-133 Hasumi Y, Baba M, Ajima R, Hasumi H, Valera VA, Klein ME, Haines DC, Merino MJ, Hong SB, Yamaguchi TP, Schmidt LS, Linehan WM: Homozygous loss of BHD causes early embryonic lethality and kidney tumor development with activation of mTORC1 and mTORC2. Proc Natl Acad Sci USA 2009;106:18722-18727.

134 Warren MB, Torres-Cabala CA, Turner ML, Merino MJ, Matrosova VY, Nickerson ML, Ma W, Linehan WM, Zbar B, Schmidt LS: Expression of Birt-Hogg-Dubé gene mRNA in normal and neoplastic human tissues. Mod Pathol 2004;17:998-1011.

-135 Adley BP, Smith ND, Nayar R, Yang XJ: BirtHogg-Dubé syndrome: clinicopathologic findings and genetic alterations. Arch Pathol Lab Med 2006;130:1865-1870.

136 Baba M, Hong SB, Sharma N, Warren MB, Nickerson ML, Iwamatsu A, Esposito D, Gillette WK, Hopkins RF 3rd, Hartley JL, Furihata M, Oishi S, Zhen W, Burke TR Jr, Linehan WM, Schmidt LS, Zbar B: Folliculin encoded by the $B H D$ gene interacts with a binding protein, FNIP1, and AMPK, and is involved in AMPK and mTOR signaling. Proc Natl Acad Sci USA 2006;103:15552-15557.
137 Furuya M, Tanaka R, Koga S, Yatabe Y, Gotoda H, Takagi S, Hsu YH, Fujii T, Okada A, Kuroda N, Moritani S, Mizuno H, Nagashima Y, Nagahama K, Hiroshima K, Yoshino I, Nomura F, Aoki I, Nakatani Y: Pulmonary cysts of Birt-Hogg-Dubé syndrome: a clinicopathologic and immunohistochemical study of 9 families. Am J Surg Pathol 2012;36:589-600.

138 Goncharova EA, Goncharov DA, James ML, Atochina-Vasserman EN, Stepanova V, Hong SB, Li H, Gonzales L, Baba M, Linehan WM, Gow AJ, Margulies S, Guttentag S, Schmidt LS, Krymskaya VP: Folliculin controls lung alveolar enlargement and epithelial cell survival through E-cadherin, LKB1, and AMPK. Cell Rep 2014;7:412-423.

139 Khabibullin D, Medvetz DA, Pinilla M, Hariharan V, Li C, Hergrueter A, Laucho Contreras $\mathrm{M}$, Zhang E, Parkhitko A, Yu JJ, Owen CA, Huang H, Baron RM, Henske EP: Folliculin regulates cell-cell adhesion, AMPK, and mTORC1 in a cell-type-specific manner in lung-derived cells. Physiol Rep 2014;2:e12107.

140 Dal Sasso AA, Belém LC, Zanetti G, Souza CA, Escuissato DL, Irion KL, Guimarães MD, Marchiori E: Birt-Hogg-Dubé syndrome. State-of-the-art review with emphasis on pulmonary involvement. Respir Med 2015;109:289-296.

141 Kennedy JC, Khabibullin D, Henske EP: Mechanisms of pulmonary cyst pathogenesis in Birt-Hogg-Dubé syndrome: the stretch hypothesis. Semin Cell Dev Biol 2016;52: $47-52$.

142 Graham RB, Nolasco M, Peterlin B, Garcia CK: Nonsense mutations in folliculin presenting as isolated familial spontaneous pneumothorax in adults. Am J Respir Crit Care Med 2005;172:39-44.

143 Painter JN, Tapanainen H, Somer M, Tukiainen P, Aittomäki K: A 4-bp deletion in the Birt-Hogg-Dubé gene (FLCN) causes dominantly inherited spontaneous pneumothorax. Am J Hum Genet 2005;76:522-527.

144 Gunji Y, Akiyoshi T, Sato T, Kurihara M, Tominaga S, Takahashi K, Seyama K: Mutations of the Birt-Hogg-Dubé gene in patients with multiple lung cysts and recurrent pneumothorax. J Med Genet 2007;44:588-593.

145 Fröhlich BA, Zeitz C, Mátyás G, Alkadhi H, Tuor C, Berger W, Russi EW: Novel mutations in the folliculin gene associated with spontaneous pneumothorax. Eur Respir J 2008;32:1316-1320.

146 Ren HZ, Zhu CC, Yang C, Chen SL, Xie J, Hou YY, Xu ZF, Wang DJ, Mu DK, Ma DH, Wang Y, Ye MH, Ye ZR, Chen BF, Wang CG, Lin J, Qiao D, Yi L: Mutation analysis of the FLCN gene in Chinese patients with sporadic and familial isolated primary spontaneous pneumothorax. Clin Genet 2008;74:178-183.

147 Kunogi M, Kurihara M, Ikegami TS, Kobayashi T, Shindo N, Kumasaka T, Gunji Y, Kikkawa M, Iwakami S, Hino O, Takahashi $\mathrm{K}$, Seyama K: Clinical and genetic spectrum of Birt-Hogg-Dubé syndrome patients in whom pneumothorax and/or multiple lung cysts are the presenting feature. J Med Genet 2010;47:281-287.

148 Gupta N, Seyama K, McCormack FX: Pulmonary manifestations of Birt-Hogg-Dubé syndrome. Fam Cancer 2013;12:387-396.

149 Menko FH, van Steensel MA, Giraud S, Friis-Hansen L, Richard S, Ungari S, Nordenskjöld M, Hansen TV, Solly J, Maher ER; European BHD Consortium: Birt-Hogg-Dubé syndrome: diagnosis and management. Lancet Oncol 2009;10:1199-1206.

150 Murakami Y, Wataya-Kaneda M, Tanaka $\mathrm{M}$, Takahashi A, Tsujimura A, Inoue $\mathrm{K}$, Nonomura N, Katayama I: Two Japanese cases of Birt-Hogg-Dubé syndrome with pulmonary cysts, fibrofolliculomas, and renal cell carcinomas. Case Rep Dermatol 2014;6:20-28.

151 Furuya M, Yao M, Tanaka R, Nagashima Y, Kuroda N, Hasumi H, Baba M, Matsushima J, Nomura F, Nakatani Y: Genetic, epidemiologic and clinicopathologic studies of Japanese Asian patients with Birt-Hogg-Dubé syndrome. Clin Genet 2016;90:403-412.

152 Park HJ, Park CH, Lee SE, Lee GD, Byun MK, Lee S, Lee KA, Kim TH, Kim SH, Yang SY, Kim HJ, Ahn CM: Birt-Hogg-Dubé syndrome prospectively detected by review of chest computed tomography scans. PLoS One 2017;12:e0170713.

153 Zbar B, Alvord WG, Glenn G, Turner M, Pavlovich CP, Schmidt L, Walther M, Choyke P, Weirich G, Hewitt SM, Duray P, Gabril F, Greenberg C, Merino MJ, Toro J, Linehan WM: Risk of renal and colonic neoplasms and spontaneous pneumothorax in the Birt-Hogg-Dubé syndrome. Cancer Epidemiol Biomarkers Prev 2002;11:393-400.

154 Tomassetti S, Carloni A, Chilosi M, Maffe A, Ungari S, Sverzellati N, Gurioli C, Casoni G, Romagnoli M, Gurioli C, Ravaglia C, Poletti V: Pulmonary features of Birt-Hogg-Dubé syndrome: cystic lesions and pulmonary histiocytoma. Respir Med 2011;105:768-774.

155 Cooley J, Lee YCG, Gupta N: Spontaneous pneumothorax in diffuse cystic lung diseases. Curr Opin Pulm Med 2017;23:323-333.

156 Houweling AC, Gijezen LM, Jonker MA, van Doorn MB, Oldenburg RA, van SpaendonckZwarts KY, Leter EM, van Os TA, van Grieken NC, Jaspars EH, de Jong MM, Bongers EM, Johannesma PC, Postmus PE, van Moorselaar RJ, van Waesberghe JH, Starink TM, van Steensel MA, Gille JJ, Menko FH: Renal cancer and pneumothorax risk in BirtHogg-Dubé syndrome; an analysis of 115 FLCN mutation carriers from 35 BHD families. Br J Cancer 2011;105:1912-1919.

-157 Toro JR, Wei MH, Glenn GM, Weinreich M, Toure O, Vocke C, Turner M, Choyke P, Merino MJ, Pinto PA, Steinberg SM, Schmidt LS, Linehan WM: BHD mutations, clinical and molecular genetic investigations of Birt-Hogg-Dubé syndrome: a new series of 50 families and a review of published reports. J Med Genet 2008;45:321-331. 
158 Johannesma PC, van de Beek I, van der Wel JW, Paul MA, Houweling AC, Jonker MA, van Waesberghe JH, Reinhard R, Starink TM, van Moorselaar RJ, Menko FH, Postmus PE: Risk of spontaneous pneumothorax due to air travel and diving in patients with Birt-Hogg-Dubé syndrome. Springerplus 2016;5:1506.

159 Gupta N, Kopras EJ, Henske EP, James LE, El-Chemaly S, Veeraraghavan S, Drake MG, McCormack FX: Spontaneous pneumothoraces in patients with Birt-Hogg-Dubé syndrome. Ann Am Thorac Soc 2017;14:706713.

160 Postmus PE, Johannesma PC, Menko FH, Paul MA: In-flight pneumothorax: diagnosis may be missed because of symptom delay. Am J Respir Crit Care Med 2014;190:704705.

161 Kluger N, Giraud S, Coupier I, Avril MF, Dereure O, Guillot B, Richard S, Bessis D: BirtHogg-Dubé syndrome: clinical and genetic studies of 10 French families. Br J Dermatol 2010;162:527-537.

162 Onuki T, Goto Y, Kuramochi M, Inagaki M, Bhunchet E, Suzuki K, Tanaka R, Furuya M: Radiologically indeterminate pulmonary cysts in Birt-Hogg-Dubé syndrome. Ann Thorac Surg 2014;97:682-685.

163 Ayo DS, Aughenbaugh GL, Yi ES, Hand JL, Ryu JH: Cystic lung disease in Birt-HoggDubé syndrome. Chest 2007;132:679-684.

164 Skolnik K, Tsai WH, Dornan K, Perrier R, Burrowes PW, Davidson WJ: Birt-HoggDubé syndrome: a large single family cohort. Respir Res 2016;17:22.

165 Tobino K, Hirai T, Johkoh T, Kurihara M, Fujimoto K, Tomiyama N, Mishima M, Takahashi K, Seyama K: Differentiation between Birt-Hogg-Dubé syndrome and lymphangioleiomyomatosis: quantitative analysis of pulmonary cysts on computed tomography of the chest in 66 females. Eur J Radiol 2012;81:1340-1346.

166 Nishida C, Yatera K, Yamasaki K, Torii R, Kawanami $\mathrm{Y}$, Kawanami T, Ishimoto $\mathrm{H}$, Shibuya R, Takenaka M, Yamada S, Kasai T, Tanaka F, Mukae H: Possible familial case of Birt-Hogg-Dubé syndrome complicated with lung cancer: a possible link between these two disease entities. Respir Med 2015; 109:923-925.

167 Benusiglio PR, Giraud S, Deveaux S, Méjean A, Correas JM, Joly D, Timsit MO, Ferlicot S, Verkarre V, Abadie C, Chauveau D, Leroux D, Avril MF, Cordier JF, Richard S; French National Cancer Institute Inherited Predisposition to Kidney Cancer Network: Renal cell tumour characteristics in patients with the Birt-Hogg-Dubé cancer susceptibility syndrome: a retrospective, multicentre study. Orphanet J Rare Dis 2014;9:163.

168 Vincent A, Farley M, Chan E, James WD: Birt-Hogg-Dubé syndrome: a review of the literature and the differential diagnosis of firm facial papules. J Am Acad Dermatol 2003;49:698-705.
169 Welsch MJ, Krunic A, Medenica MM: BirtHogg-Dubé syndrome. Int J Dermatol 2005; 44:668-673.

-170 Tellechea O, Cardoso JC, Reis JP, Ramos L, Gameiro AR, Coutinho I, Baptista AP: Benign follicular tumors. An Bras Dermatol 2015;90:780-796; quiz 797-798.

171 Misago N, Kimura T, Narisawa Y: Fibrofolliculoma/trichodiscoma and fibrous papule (perifollicular fibroma/angiofibroma): a revaluation of the histopathological and immunohistochemical features. J Cutan Pathol 2009;36:943-951.

172 Luba MC, Bangs SA, Mohler AM, Stulberg DL: Common benign skin tumors. Am Fam Physician 2003;67:729-738.

173 Pavlovich CP, Grubb RL 3rd, Hurley K, Glenn GM, Toro J, Schmidt LS, Torres-Cabala C, Merino MJ, Zbar B, Choyke P, Walther MM, Linehan WM: Evaluation and management of renal tumors in the BirtHogg-Dubé syndrome. J Urol 2005;173: 1482-1486.

174 Pavlovich CP, Walther MM, Eyler RA, Hewitt SM, Zbar B, Linehan WM, Merino MJ: Renal tumors in the Birt-Hogg-Dubé syndrome. Am J Surg Pathol 2002;26:15421552.

175 Gupta S, Kang HC, Ganeshan D, Morani A, Gautam R, Choyke PL, Kundra V: The ABCs of BHD: an in-depth review of Birt-HoggDubé syndrome. AJR Am J Roentgenol 2017, Epub ahead of print.

176 Lindor NM, Kasperbauer J, Lewis JE, Pittelkow M: Birt-Hogg-Dubé syndrome presenting as multiple oncocytic parotid tumors. Hered Cancer Clin Pract 2012;10:13.

177 Maffé A, Toschi B, Circo G, Giachino D, Giglio S, Rizzo A, Carloni A, Poletti V, Tomassetti S, Ginardi C, Ungari S, Genuardi M: Constitutional FLCN mutations in patients with suspected Birt-Hogg-Dubé syndrome ascertained for non-cutaneous manifestations. Clin Genet 2011;79:345-354.

178 Gupta N, Sunwoo BY, Kotloff RM: BirtHogg-Dubé syndrome. Clin Chest Med 2016;37:475-486.

179 Nahorski MS, Lim DH, Martin L, Gille JJ, McKay K, Rehal PK, Ploeger HM, van Steensel M, Tomlinson IP, Latif F, Menko $\mathrm{FH}$, Maher ER: Investigation of the BirtHogg-Dubé tumour suppressor gene $(F L C N)$ in familial and sporadic colorectal cancer. J Med Genet 2010;47:385-390.

180 Agarwal PP, Gross BH, Holloway BJ, Seely J, Stark P, Kazerooni EA: Thoracic CT findings in Birt-Hogg-Dubé syndrome. AJR Am J Roentgenol 2011;196:349-352.

181 Johannesma PC, Houweling AC, van Waesberghe JH, van Moorselaar RJ, Starink TM, Menko FH, Postmus PE: The pathogenesis of pneumothorax in Birt-Hogg-Dubé syndrome: a hypothesis. Respirology 2014;19: 1248-1250.

182 Butnor KJ, Guinee DG Jr: Pleuropulmonary pathology of Birt-Hogg-Dubé syndrome. Am J Surg Pathol 2006;30:395-399.
83 Koga S, Furuya M, Takahashi Y, Tanaka R, Yamaguchi A, Yasufuku K, Hiroshima K, Kurihara M, Yoshino I, Aoki I, Nakatani Y: Lung cysts in Birt-Hogg-Dubé syndrome: histopathological characteristics and aberrant sequence repeats. Pathol Int 2009;59: 720-728.

184 Kumasaka T, Hayashi T, Mitani K, Kataoka H, Kikkawa M, Tobino K, Kobayashi E, Gunji Y, Kunogi M, Kurihara M, Seyama K Characterization of pulmonary cysts in BirtHogg-Dubé syndrome: histopathological and morphometric analysis of 229 pulmonary cysts from 50 unrelated patients. Histopathology 2014;65:100-110.

185 Johannesma PC, Reinhard R, Kon Y, Sriram JD, Smit HJ, van Moorselaar RJ, Menko FH, Postmus PE; Amsterdam BHD Working Group: Prevalence of Birt-Hogg-Dubé syndrome in patients with apparently primary spontaneous pneumothorax. Eur Respir J 2015;45:1191-1194.

186 Stamatakis L, Metwalli AR, Middelton LA, Linehan WM: Diagnosis and management of BHD-associated kidney cancer. Fam Cancer 2013;12:397-402.

187 Jamis-Dow CA, Choyke PL, Jennings SB, Linehan WM, Thakore KN, Walther MM: Small $(<$ or $=3-\mathrm{cm})$ renal masses: detection with CT versus US and pathologic correlation. Radiology 1996;198:785-788

188 Schmidt LS, Linehan WM: Clinical features, genetics and potential therapeutic approaches for Birt-Hogg-Dubé syndrome. Expert Opin Orphan Drugs 2015;3:15-29.

189 Nakamura M, Yao M, Sano F, Sakata R, Tatenuma T, Makiyama K, Nakaigawa N, Kubota Y: A case of metastatic renal cell carcinoma associated with Birt-Hogg-Dubé syndrome treated with molecular-targeting agents (in Japanese). Hinyokika Kiyo 2013; 59:503-506.

190 Gambichler T, Wolter M, Altmeyer P, Hoffman K: Treatment of Birt-Hogg-Dubé syndrome with erbium:YAG laser. J Am Acad Dermatol 2000;43:856-858.

191 Jacob CI, Dover JS: Birt-Hogg-Dubé syndrome: treatment of cutaneous manifestations with laser skin resurfacing. Arch Dermatol 2001;137:98-99.

192 Al-Daraji WI, Al-Razag ZA, Craven N, Twaij Z: Multiple hereditary facial papules. Clin Exp Dermatol 2005;30:309-310.

193 Felton SJ, Madan V: Facial and upper body papules in a patient with a family history of recurrent pneumothorax. JAMA 2012;308: 2622-2623.

194 Gijezen LM, Vernooij M, Martens H, Oduber CE, Henquet CJ, Starink TM, Prins MH, Menko FH, Nelemans PJ, van Steensel MA Topical rapamycin as a treatment for fibrofolliculomas in Birt-Hogg-Dubé syndrome: a double-blind placebo-controlled randomized split-face trial. PLoS One 2014;9:e99071. 